\title{
Testing the Pecking Order Theory with Financial Constraints
}

\author{
HUILI CHANG ${ }^{\mathrm{a}}$ and FRANK M. SONG ${ }^{\mathrm{b}}$
}

\begin{abstract}
This paper points out that two crucial market imperfections ignored by the pecking order theory can explain why small and high-growth firms tend to issue equity, i.e., credit rationing caused by information asymmetry in the debt market, and the frictions from the supply side of capital. We propose financial constraints as proxy for these imperfections, and argue that small and high-growth firms' choice of issuing equity mainly reflects the financial constraints they face rather than contradicts pecking order. Empirically, we first show that financial constraints are different from debt capacity proposed by Lemmon and Zender (2010) to solve the same question. Next, we demonstrate that financially constrained firms indeed heavily rely on equity for external finance, and once financial constraints are controlled for, pecking order provides a good description of firms' financing behaviors.
\end{abstract}

\section{JEL classification: G32}

Keywords: financial constraints, pecking order, security issue, capital structure

\footnotetext{
a Huili Chang, School of Economics and Finance, The University of Hong Kong, +852 (6571 5825), EFM code: 140, kellyhlchang@gmail.com. Huili Chang will attend the conference and present this paper.

b Frank M. Song, School of Economics and Finance, The University of Hong Kong, +852 (2857 8507), EFM code: 140, fmsong@econ.hku.hk.

We appreciate valuable comments from Sreedhar Bharath, Sheridan Titman, Paul Po-Hsuan Hsu, Xianming Zhou and participants in the seminar at the University of Hong Kong. We thank Chenyu Shan for help in data. We are grateful to John Graham and Jay Ritter for generously providing the tax rate and IPO data online.
} 


\section{Introduction}

The modified pecking order theory proposed by Myers (1984) and Myers and Majluf (1984) is one of the most popular capital structure theories. By assuming managers have inside information about firm value and always behave in the interests of passive existing shareholders, the Myers and Majluf (1984) model predicts that firms prefer internal to external finance, and prefer safe securities to risky ones for raising external funds. Here safe securities, also called informational insensitive securities, are defined as securities with less future value changes when managers' inside information is revealed. In particular, default-risk-free debt is the safest, risky debt less safe, hybrid securities (such as convertible bonds and preferred stocks) more risky, whereas external equity is the riskiest. Accordingly, pecking order predicts a negative correlation between profitability and leverage, a negative price impact of equity issues and a less negative impact of debt issues, which are largely confirmed by subsequent papers.

However, the validity of pecking order is far from settled. The most critical point is that pecking order fails to explain why so many firms issue equity, in particular small and high-growth firms. Based on the 157 large and mature firms, Shyam-Sunder and Myers (1999) conclude that pecking order provides a better first-order description. But Frank and Goyal (2003) do not obtain results supporting pecking order when expanding the Shyam-Sunder and Myers (1999) test to a broader sample and a longer period, and in particular, they find that pecking order works much worse for small and high-growth firms. Together with Fama and French $(2002,2005)$, they argue that since small and high-growth firms are more likely to suffer information asymmetry, their tendency to issue equity refutes pecking order.

Why do small and high-growth firms fail to follow pecking order? This paper tries to answer this question from a new perspective. On one hand, because they have far less internal funds to meet their investment demand, small and high-growth firms are more likely to be financially constrained. On the other hand, Devos et al. (2012) demonstrate that zero-debt firms do not issue debt mainly because they are financially 
constrained rather than driven by entrenched managers. They also find that the proportion of zero-debt firms increases dramatically from $8.4 \%$ in 1990 to $18.6 \%$ in 2008, which is coincident with the fact that publicly listed firms are increasingly dominated by small firms with low profitability and strong growth opportunities as documented by Fama and French (2001). Therefore, because of financial constraints, small and high-growth firms may have no access to the debt market or the access is extremely costly, while the equity market is less costly considering their good growth prospects. So their tendency to issue equity mainly reflects the financial constraints they face rather than contradicts pecking order.

This explanation can also be justified theoretically. That is, financial constraints can account for the two crucial market imperfections that are missing in the pecking order theory. First, information asymmetry can lead to credit rationing in the debt market. Pecking order only emphasizes that information asymmetry can cause the underpricing in the equity market, but fails to consider that information asymmetry can also have adverse effects in the debt market. According to Jaffee and Russell (1976) and Stiglitz and Weiss (1981, 1983), because of asymmetric information between borrowers and banks, increase in interest rate charged will increase the riskiness of the loan. As a result, the optimal interest rate that maximizes banks' profits will not be the same one that clears the loanable funds market. There will be excessive demand for loanable funds, and some firms will be shut out of the debt market. For these firms, the cost of issuing debt is infinite, while the cost of issuing equity is finite, and so issuing equity is an optimal choice. Second, pecking order implicitly assumes that the supply side of capital is completely flexible, and thus the price of a security only depends on the demand side, i.e., firm fundamentals. Nevertheless, Baker (2009) argues that the supply side of capital is not perfectly flexible due to investor tastes, limited intermediation and corporate opportunism, and it can to some extent affect firms' financing choice. Here we use financial constraints to account for the extreme situation of credit rationing in the debt market and also the frictions from the supply side of capital. That is because financial constraints reflect the difference in costs between internal and external finance, and are the interaction 
outcome of both the demand and supply sides of capital. The more financially constrained a firm is, the more likely it is credit rationed in the debt market and has to use equity to raise external funds, and the more likely it is impacted by the frictions from the supply side of capital.

Since there is no commonly agreed measure of financial constraints, we adopt four frequently used criteria based on prior studies. First, in a similar spirit to Fazzari, Hubbard and Petersen (1988) who use dividend ratio, we use the payout ratio calculated as the ratio of dividends plus repurchases to operating income following Almeida, Campello and Weisbach (2004). Second, we use the KZ index first proposed by Lamont et al. (2001) based on empirical results from Kaplan and Zingales (1997). Third, we use the WW index from Whited and Wu (2006). Finally, as in Li (2011), we also use the SA index proposed by Hadlock and Pierce (2010).

For the empirical part, we first employ the Shyam-Sunder and Myers (1999) test and also the Lemmon and Zender (2010) modification to show that financial constraints are different from debt capacity. Following the financial constraints literature, we define firms in top (bottom) three deciles based on each financial constraints index ${ }^{1}$ as financially constrained (unconstrained) firms. First of all, the coefficient for the squared financing deficit term for unconstrained firms is more negative. This actually differentiates financial constraints from debt capacity. According to Lemmon and Zender (2010), a more negative coefficient means a higher likelihood of being concerned over debt capacity. If financial constraints only measure a firm's debt capacity, unconstrained firms should have a high debt capacity and thus have an insignificant coefficient. But from the perspective of financial constraints, if a firm is financially unconstrained, it is free to choose debt, and is more likely to reach its debt capacity, while for a firm being constrained due to no access to the debt market, since it cannot issue debt before, it is less likely to reach its debt capacity when it is able to issue debt. It is possible a firm may be constrained due to the exhaustion of its debt capacity, but the overall effect is that financially constrained

\footnotetext{
${ }^{1}$ Here we assume that firms are ranked by their likelihood of being financially constrained. It means that we rank firms in a reverse order in terms of the payout ratio, and in the sequential order with the KZ index, WW index and SA index.
} 
firms are less concerned over debt capacity. Meanwhile, we also find that financially unconstrained firms tend to follow pecking order while constrained firms are less likely to.

Next we examine whether information asymmetry is more relevant in firms' financing choice after controlling for financial constraints. First of all, in comparison with prior studies, we use the logit regression to analyze how firms choose between equity and debt. We find that consistent with pecking order, firms with less analyst coverage or more information asymmetry are inclined to issue debt, and this relationship is stronger when we control for financial constraints. As we expect, financial constraints do affect firms' choice between equity and debt. Specifically, compared with the intermediate firms, financially constrained firms are less likely to issue debt while unconstrained firms are more likely to issue debt. Second, we employ the multinomial logit regression to analyze how firms choose among the four main financing instruments, including private equity, SEO, bank loan, and public bond. When we do not control for financial constraints, we find that the prediction of pecking order that firms prefer safe to risk securities is fairly supported. Firms followed by more analysts are more likely to issue private equity, but only marginally less likely to borrow bank loan. After we include the financial constraints deciles, firms with more analyst coverage is significantly less likely to borrow bank loan. Meanwhile, we find that financially constrained firms are less likely to issue debt, and are more likely to issue private equity. This is consistent with our argument that financially constrained firms are more likely to be credit rationed in the debt market and are more susceptible to the frictions from the supply side of capital so that they face higher costs to issue debt.

Besides controlling for financial constraints, this paper also innovates in the data used to test pecking order. First, because pecking order predicts firms' incremental financing choice, we focus on the new security issues data. This is in contrast with papers testing capital structure theories using leverage as the dependent variable (like Titman and Wessels (1988), Rajan and Zingales (1995), and Frank and Goyal (2009)). Firms' leverage is the cumulative result, and may reflect the market timing behavior, 
which is allowed in a loose version of pecking order. Second, we use the security type data directly from the new issues databases rather than infer the types of security issued based on the Compustat data. Ever since Hovakimian et al. (2001), prior literature use the classification point of 5 percent of total assets to determine which security a firm has issued. But as pointed out by Graham (2000), the Compustat issue variables cannot provide pure debt versus equity measures. For instance, the equity measure may include preferred stock issues, conversion of debt into common stock, and the exercise of stock options, which explains why using the Compustat variables identifies too many equity issues than those recorded in the new issues database. Therefore, this paper directly uses the new security issues databases. Similar to Erel et. al (2012), we use the new issues data of private equity and SEO from SDC Platinum, bank loan from Dealscan, and corporate bond and Rule 144-A debt from Mergent Fixed Investment Securities Database. We will show later that the new security issues data is indeed different from the inferred data, and it can provide a neat test of pecking order. Furthermore, this innovation in data also differentiates our paper from prior papers on security choice. Taggart (1977) does not use the security issuance data, while Marsh (1982) and Jung, Kim and Stulz (1996) only use the new issues data of equity and public bond, not including bank loan. Since bank loan is the dominant external financing source, ignoring it for the security choice analysis will bias the results.

This paper contributes to the literature in several aspects. First, it shows that after using financial constraints to account for the two crucial points missing in pecking order, the credit rationing in the debt market and the frictions from the supply side of capital, the financing behavior of small and high-growth firms is consistent with pecking order. Second, financial constraints can also explain why previous studies find that both the trade-off and pecking order theories are partially true. For financially unconstrained firms, pecking order provides a better description of their financing behavior. They will choose to issue debt except when the equity market is so favorable that the cost of issuing equity is less than that of issuing debt. For constrained firms, they will choose to issue equity most of the time except when they 
may sometimes be accessible to the debt market. Because unconstrained firms tend to be larger, and have more tangible assets, higher profitability but less growth opportunities than constrained firms, if we model the optimal leverage as the four firm characteristics proposed by Rajan and Zingales (1995), it seems plausible that firms have target leverage. Third, this paper provides direct channels through which financial constraints affect investment. On one hand, financially constrained firms rely heavily on the equity market for funding, and since the cost of issuing equity is higher than the cost of issuing debt if both markets are accessible, the higher cost of external finance will make constrained firms forgo some projects with positive NPVs. On the other hand, since the equity market is highly cyclical, it also explains why the investment of constrained firms is cyclical. Fourth, by explaining why firms do not issue debt, this paper can also help explain the debt conservatism as discussed by Minton and Wruck (2001) and Lemmon and Zender (2001). Furthermore, we directly use the new security issues data, which can provide a neat test of pecking order compared with the Compustat data.

This paper is closely related to the papers that incorporate debt capacity when testing pecking order, including Agca and Mozumdar (2007), Lemmon and Zender (2010) and Leary and Roberts (2010). Agca and Mozumdar (2007) and Lemmon and Zender (2010) argue that firms' financing choice also depends on the amount of debt a firm can support. Debt capacity is actually implied in pecking order, and as mentioned by Lemmon and Zender (2010), it is simply one form of financial constraints. We will show later that financial constraints incorporate more than debt capacity. That is, the possibility of firms being shut out of the debt market and the frictions from the supply side of capital. Besides, Leary and Roberts (2010) show that considering debt capacity cannot save pecking order.

In a similar spirit, Halov and Heider (2011) use the adverse selection cost of debt arisen by the uncertainty of risk to explain why firms may not issue debt. However, we suspect that the uncertainty of risk is highly correlated with the risk level itself. It is likely that the risk of risky firms is difficult to estimate so that their risk estimation usually has a larger standard error. This can also be seen from their first measure 
using recent asset volatilities, which is similar to the cash flow volatility or stock return volatility usually used to measure the firm risk. As far as firm risk is concerned, Helwege and Liang (1996) and Bolton and Freixas (2000) both argue that higher risk decreases the probability of firms' issuing debt. Here we control for firm risk by stock return volatility.

This paper also belongs to the financial constraints literature. Initiated by Fazzari, Hubbard and Petersen (1988), a large number of papers have studied the impact of financial constraints on firm investment (e.g., Fazzari and Petersen (1993), Kashyap et al. (1994), and Li (2009)). This paper instead focuses on the impact of financial constraints on firms' financing choice. Korajczyk and Levy (2003) also link financial constraints to capital structure, but they focus on the differential effects of macroeconomic conditions on capital structure of financially unconstrained and constrained firms. Here we control for financial constraints to test the pecking order theory.

Finally, this paper is among the tremendous papers that empirically test pecking order. This paper employs a similar method when analyzing firms' financing choice to Helwege and Liang (1996), who study the time-series evolution of IPO firms' financing decision. Since IPO firms tend to be small and high-growth firms, it is not surprising that they do not follow pecking order. In this paper, we enlarge the sample to cover both financially constrained and unconstrained firms. We also control for financial constraints and the main alternative capital structure theories, including the trade-off theory, market timing theory and agency theory. Meanwhile, Bharath, Pasquariello, and $\mathrm{Wu}$ (2009) construct an information asymmetry index based on the market's assessment of adverse selection risk, and evaluate the core assumption of pecking order that information asymmetry determines capital structure decisions. However, firms' assessment of adverse selection risk may be quite different from that of the market, and the validity of its core assumption does not automatically ensure the validity of the pecking order theory itself.

This paper is organized as follows. Session 2 describes the data and methodology. Session 3 analyzes the empirical results. Session 4 concludes. 


\section{Data and Methodology}

\subsection{Sample}

For the new issues data, we exclude any kind of convertible securities and preferred securities, since these securities are hybrids of both equity and debt, and we want to conduct a clean test of pecking order. Similar to Erel et. al (2012), we use the seasoned equity offering (SEO) and private equity data from the global new issues database in SDC Platinum, bank loan data from Dealscan, and corporate bond and Rule 144-A debt data from Mergent Fixed Investment Securities Database (FISD). Following Gomes and Phillips (2012), for the bank loan data, we exclude short-term loans (loans with less than 1 year of maturity), credit lines and records belonging to a loan type that is not a long-term commercial loan or revolving credit line (e.g., guarantee, fixed-rate bond or $\mathrm{CD}$, etc.). For the corporate bond data, we exclude the asset-backed, convertible, preferred, private placements, unit deals and foreign currency denominated records that seem irrelevant to capital structure, and we keep Rule 144-A debt data because Gomes and Phillips (2012) find that 144-A debt issues and public bond issues are similar.

The sample period for new issues data is from 1988 to 2008 , because according to WRDS Overview of Dealscan, bank loan data recorded in Dealscan is not well populated before 1988 , while there are very few observations after 2008 , which may be due to the financial crisis, and we do not want this to bias our results.

We use the financial statement data from Compustat and stock data from CRSP. Each category of new issues data is first merged with Compustat based on different available identifiers ${ }^{2}$, and we exclude the observations with offering amount missing or equal to zero. We treat the issues of the same security within one fiscal year as one observation, because there may be several tranches for one issue. For instance, the same SEO issued in the US and in the global markets are recorded as two different

\footnotetext{
2 We use 9-digit CUSIP to identify SEO. But for private placements of equity, 9-digit CUSIP is available for a small subset of observations, so we use 6-digit CUSIP whenever the 9-digit one is missing. We use the linking table as in Chava and Roberts (2008) to merge Dealscan with Compustat data, and we use 6-digit CUSIP for the corporate bond data as it is the only identifier provided.
} 
observations, and a syndicated loan package usually has several facilities.

We keep public companies listed in NYSE, American Exchange and Nasdaq, as these are large firms whose new security issues are more likely to be covered by databases. We exclude financial firms (SIC code: 6000-6999) and utilities (SIC code: 4900-4999), and firms involved in a significant merger/acquisition (Compustat footnote code $A B$ ). Firms that report format code 5, which is for the Canadian file, and firms with missing or zero total assets are also excluded. We recode the missing values of labeled variables in Table 8 of Frank and Goyal (2003) with zero, and also winsorize the continuous variables (excluding the market variables) at both the bottom and top 1 percent tails to limit the effect of outliers.

We use the IBES data to obtain the analyst coverage information. As used in Chang et al. (2006), we use the number of analysts as the maximum number of analysts that make annual earnings forecasts any month over a 12-month period, to measure information asymmetry. To avoid the endogeneity problem, we use the 3-year lagged value.

\subsection{Methodology and Variables}

To illustrate that financial constraints are different from debt capacity, we use the Shyam-Sunder and Myers (1999) test and also the Lemmon and Zender (2010) modified regression. As in Equation (1), Shyam-Sunder and Myers (1999) focus on the prediction of pecking order that firms should use debt to fund financing deficit, and propose that there should be one-by-one change between net debt issues and financing deficit. The pecking order hypothesis is that $b_{P O}=1$. To calculate financing deficit $D E F_{i t}$, Shyam-Sunder and Myers (1999) also include the current portion of long-term debt. Here we follow Frank and Goyal (2003) in calculating the financing deficit, which equals the use of financing (cash dividend plus investments plus change in working capital) minus the internal financing (internal cash flow). Lemmon and Zender (2010) argue that Equation (1) fails to consider the concern over debt capacity, and suggest adding the squared financing deficit term to Equation (1) to account for 
the concavity relationship between net debt issues and financing deficit. To demonstrate that financial constraints reflect things other than debt capacity, we run Equation (1) for the unconstrained, intermediate, and constrained firms, respectively, and compare the results. As Petersen (2009) suggests, we correct the t-statistics by clustering at both the firm and year levels for the regressions here and also the logit regressions below, while correct the t-statistics by clustering at the firm level for the multinomial logit regressions later.

$$
\Delta D_{i t}=a+b_{P O} D E F_{i t}+e_{i t},(1)
$$

where $D E F_{i t}=D I V_{i t}+I_{i t}+\Delta W_{i t}-C_{i t}=\Delta D_{i t}+\Delta E_{i t}$.

To classify firms into unconstrained and constrained firms, we base on four frequently used financial constraints measures by prior studies. Appendix A provides details on how to construct them. First is the payout ratio calculated as the ratio of dividends plus repurchases to operating income as in Almeida, Campello and Weisbach (2004). As external finance is more costly than internal funds, it is rational for financially constrained firms to retain most of their operating incomes and thus have a lower payout ratio. Second, we choose the KZ index first proposed by Lamont et al. (2001) according to the ordered logit regression results of Kaplan and Zingales (1997) on the probability of being classified as financially constrained. They place the 49 low dividend firms identified by Fazzari, Hubbard and Petersen (1988) into five different categories from least likely to most likely being financially constrained based on the qualitative information in firms' annual report or 10-K. The KZ index is a linear combination of cash flow to capital, dividends to capital, and cash holdings to capital with negative coefficients, and Tobin's Q and debt to total capital with positive coefficients, and it is larger for firms with more financial constraints. Third, we calculate the Whited and $\mathrm{Wu}$ (2006) index which is constructed via generalized method of moments (GMM) estimation of an investment Euler equation. The WW index is a linear combination of cash flow to total assets, dividend-paying dummy, long-term debt to total assets, log of total assets, firm's 3-digit industry sales growth, and firm's sale growth. Finally, we compute the SA index proposed by Hadlock and 
Pierce (2010). They use a similar method to Kaplan and Zingales (1997), but they apply it to a broad and representative sample. They find that firm size and age are the most reliable predictors of financial constraints, and they propose the SA index as a combination of firm size and age. Here firm size is computed as the natural log of inflation-adjusted total assets, and firm age as the number of years the firm has been on Compustat with a non-missing stock price following Hadlock and Pierce (2010).

$$
P\left(\operatorname{Debt}_{i, t}=1\right)=\operatorname{Logit}\left(\beta X_{i, t-1}+\varepsilon_{i, t}\right)
$$

To analyze the financing choice, following Hovakimian et al. (2001), we exclude the firm-year observations with multiple issues. To compare with previous studies, we first run a logit regression to analyze firms' choice between equity and debt as shown by Equation (2). The dependent variable equals one if firm borrows bank loan or issues public bond and zero otherwise. For the independent variables, we first use the number of analysts to measure information asymmetry. As mentioned before, it is the maximum number of analysts that make annual earnings forecasts any month over a 12-month period with a 3-year lag. Then we include the unconstrained and constrained dummies to find out how financial constraints affect firms' choice between debt and equity. Finally, we control for the variables that are found to affect firms' choice between equity and debt (e.g., Hovakimian et al. (2001) and Chang et al. (2006)), including Firm size, Log of age, Leverage deviation (market leverage minus target leverage), Three-year mean ROA, and Market-to-book ratio, Dummy for $\mathrm{M} / \mathrm{B}>1$, Dilution dummy, Tangible assets, S\&P rating dummy, Asset growth rate, R\&D ratio, R\&D dummy, Share turnover, Z-score, and Stock return volatility. Here we estimate the target leverage using the partial-adjustment model in Flannery and Rangan (2006). Details on the estimation of target leverage are given in Appendix B, and explanations of other control variables can be found in Appendix C.

Second, a multinomial logit regression is employed to compare firms issuing private equity, SEO, bank loan and bond. Specifically, for the dependent variable, we create a discrete variable issue: 1 for private equity, 2 for SEO, 3 for bank loan, and 4 for public bond. Here we use SEO firms as the base outcome. The independent 
variables mainly follow the logit regression above, except that we use the deciles based on each financial constraints index to replace the unconstrained and constrained dummies. That's because when constrained firms seldom issue debt and unconstrained firms seldom issue equity, the coefficients for the unconstrained and constrained dummies will be inaccurately estimated.

\section{Empirical Results}

\subsection{Univariate Analysis}

[Insert Table 1 here]

Table 1 shows the pre-issue firm characteristics for each financing choice. There are 69,411 firm-year observations from 1987 to 2007, approximately 3,300 firms per year. Among them, 1.42 percent issue private equity, 4.12 percent issue SEOs, 20.90 percent borrow bank loans, and 4.58 percent issue public bond. It is reasonable that bank loan is most frequently used to raise funds given that the parties involved in bank loan are far less than those involved in SEO or public bond and banks are specialized financial intermediary relative to private equity investors.

The mean and median statistics of each variable give a similar pattern. From firms issuing private equity to public bond, firm size and age monotonically increase, while information asymmetry and financial constraints decrease. It is not surprising that larger and older firms tend to issue public bond. First, larger firms can easily afford the fixed issuance cost, and they are more diversified to have less volatile cash flows. Second, larger and older firms are more likely to have accumulated the reputation to issue in the bond market. It is consistent with our hypothesis that debt issuers are less likely to be financially constrained, while the fact that debt issuers are followed by more analysts seems to contradict the pecking order theory. Nevertheless, we will show in the multivariate analysis that this is because financial analysts are inclined to cover more transparent firms and pecking order is supported after controlling for other firm characteristics. Consistent with Fama and French (2002) among others, firms issuing debt are more profitable than firms issuing equity, while the growth prospects 
for equity issuers are better as reflected in higher market to book ratio, R\&D ratio and asset growth rate. Furthermore, debt issuers also have higher tangible assets and less risk, and are less likely to default. Contrary to the prediction of the trade-off theory, although equity issuers have lower target leverage, their market leverage is still below the target leverage and they should issue debt rather than equity. Market timing theory is fairly supported as the firm stock return is a little higher for the equity issuers, while the difference in share turnover is not significant. As in Hovakimian et al. (2001), the data suggest that managers do have a role in the financing choice, as firms tend to issue equity when market to book ratio is high and tend to issue debt if issuing equity will dilute the earnings price ratio.

\section{[Insert Table 2 here]}

Table 2 shows the distribution of each type of security issues across years. The patterns here are similar to previous studies, and confirm that our security issues data is representative. There is a boom in private equity after year 2000, the SEO distribution is consistent with the US IPO pattern provided on Jay Ritter's website, the bank loan and public bond issues increase over time, while decrease around year 2006 due to the financial crisis.

\section{[Insert Table 3 here]}

Next, we compare the four financial constraints measures adopted. In our latter analysis, the four measures do not always give the same results, so we have to evaluate the different measures before we can draw a reliable conclusion. Panel A in Table 3 shows the correlation matrix between the constrained and unconstrained firms based on any two of the criteria. If all the measures are positively correlated, the numbers in the diagonal should dominate those off the diagonal. This is true for all the criteria except for the KZ index. Panel B tells a similar story. It shows the mean and median statistics of key firm characteristics that are closely related to financial constraints. For all the measures except for the $\mathrm{KZ}$ index, unconstrained firms are followed by more analysts, have higher tangible assets, and are more likely to have an S\&P debt rating than constrained firms as expected. But in terms of the $\mathrm{KZ}$ index, constrained firms have higher tangible assets and are more likely to have an S\&P debt 
rating than unconstrained firms. Therefore, consistent with Whited and $\mathrm{Wu}(2006)$ and Hadlock and Pierce (2010), both panels suggest that the KZ index may not be a reliable measure of financial constraints. More important, Panel B compares the financing choice between constrained and unconstrained firms based on each of the financial constraints criteria. Based on all the four criteria, the proportion of constrained firms that issue private equity or SEO is much higher than that of unconstrained firms. Except for the $\mathrm{KZ}$ index, the proportion of unconstrained firms that borrow bank loan or issue public bond is significantly higher than that of constrained firms. This is consistent with our argument that financially constrained firms may not be accessible to the debt market and thus are forced to issue equity.

[Insert Table 4 here]

Table 4 shows the dramatic difference between new security issues data and Compustat data in terms of which type of security issued. From Panel A, we can see that 10,611 firm-year observations have net equity issues exceeding 5 percent of total assets according to the Compustat data, but only 3,845 firm-year observations are recorded in the new security issues data as either private equity or SEO. This can be explained by Graham (2000) that the Compustat issue variables cannot provide pure debt versus equity measures. In particular, the equity measure may include preferred stock issues, conversion of debt into common stock and the exercise of stock options. These represent firms' passive issue of equity, and the problems faced may be quite different. For instance, stock options are issued to solve the incentive problems. On the contrary, Panel B shows that the new debt issues variable in Compustat tells us less debt issues. There are 13,140 firm-year observations that have net debt issues exceed 5 percent of total assets, while the new security issues data tell us that 17,679 firm-year observations borrow either bank loan or public bond. Also over a half of new debt issues (9,339 for bank loan issues and 1,702 for public bond issues) are not identified by the 5 percent criterion based on the Compustat data. Overall, the new issues inferred from Compustat data cannot accurately determine whether a new security is issued or which type of security is issued. Thus we use the new security issues data to test pecking order. 


\section{[Insert Table 5 here]}

To control for the trade-off theory, we first have to estimate firms' target leverage. Here we use the partial-adjustment model proposed by Flannery and Rangan (2006), as their model specification is theoretically preferable. Table 5 shows the five main regression results presented in Table 2 of Flannery and Rangan (2006). The results here are basically the same with theirs, while the specific coefficients vary considering that we use a different estimation period.

\subsection{Financial constraints are different from debt capacity}

To differentiate financial constraints from debt capacity, in this part, we run the Shyam-Sunder and Myers (1999) test and also the Lemmon and Zender (2010) modified regression. If financial constraints represent the same things with debt capacity, according to Lemmon and Zender (2010), the coefficient of the squared financing deficit term for financially unconstrained firms should be insignificant.

\section{[Insert Figure 1 here]}

Before running the regressions, we first graphically analyze the relations among the financing deficit, net debt issues, and net equity issues for firms on different financial constraints levels based on the SA index. As shown in Figure 1, for financially unconstrained firms, financing deficit is predominantly funded by net debt issues, while net equity issues play a negligible role. For constrained firms, things are just the opposite. Financing deficit is solely financed by net equity issues, while net debt issues are irrelevant. Situation for the intermediate firms goes in-between. Both net equity issues and net debt issues are correlated with financing deficit, though net equity issues seem more important. This is consistent with our hypothesis. Financially constrained firms have to rely on the equity market for external finance, while unconstrained firms can and will usually choose debt for external finance even though they sometimes time the equity market.

[Insert Table 6 here]

Table 6 shows the results of the Shyam-Sunder and Myers (1999) regression and also the Lemmon and Zender (2010) modified regression for different types of firms 
based on the SA index. Different from the results in Table 4 of Lemmon and Zender (2010), here the coefficient of the squared financing deficit term for unconstrained firms is the most negative, while that for constrained firms is the least negative. According to Lemmon and Zender (2010), a negative coefficient means that firms are concerned about debt capacity. If financial constraints are the same with debt capacity, unconstrained firms should have a high debt capacity and thus have an insignificant coefficient. Therefore, the more negative coefficient for unconstrained firms shows that financial constraints reflect different things from debt capacity. Besides, our hypothesis can also explain this more negative coefficient. A financially unconstrained firm can and will usually choose debt to raise external funds, and thus is more likely to reach its debt capacity, while for a firm being constrained due to no access to the debt market, since it cannot issue debt before, it is less likely to reach its debt capacity when it is able to issue debt. It is possible a firm may be constrained due to the exhaustion of its debt capacity, but the overall effect is that financially constrained firms are less concerned over debt capacity than unconstrained firms. Meanwhile, the difference in the coefficient of financing deficit between unconstrained and constrained firms is significantly larger than the difference between high and low debt capacity firms in Lemmon and Zender (2010), which also supports our argument that debt capacity is simply one form of financial constraints and financial constraints incorporate things more than debt capacity. On the other hand, consistent with Lemmon and Zender (2010), we also find that unconstrained firms are more likely to follow pecking order, and adding the squared financing deficit term to account for debt capacity can increase the explanatory power of pecking order.

In the analysis above, we use the SA index as it is the latest index that is found to reliably measure financial constraints. The results basically remain when the other three measures are used except for the $\mathrm{KZ}$ index. As mentioned before, the $\mathrm{KZ}$ index seems to give the opposite results to the other measures.

\subsection{Testing pecking order after controlling for financial constraints}

Since pecking order predicts firms prefer debt to raise external funds, to test 
pecking order is to test what determines firms' incremental financing choice. First, for the purpose of comparing with previous studies, we run a logit regression to analyze firms' choice between debt and equity. Second, to examine how firms choose among private equity, SEO, bank loan and public bond, we use a multinomial logit regression.

\section{[Insert Table 7 here]}

Table 7 shows the logit regression results for the choice between debt and equity. Column (1) shows the results when financial constraints are not controlled for, while Column (2) to (5) include the unconstrained and constrained dummies based on each of the four financial constraints criteria, respectively. Here and also in the latter analysis we will focus on the results based on the payout ratio because the other three measures may be to some extent compromised. First, as discussed before, the KZ index itself may not be a reliable measure of financial constraints. Second, one of the components of the WW index is firm size, which is included as an independent variable. Third, the SA index is a nonlinear combination of firm size and log of age, which are both included as independent variables. More important, we cannot drop firm size and log of age as independent variables, as they are crucial to control for the endogeneity problems. That is, larger and older firms are more likely to be followed by more analysts. On the other hand, if we regard firm size and age as reliable predictors of financial constraints as found by Hadlock and Pierce (2010), the positive coefficients of these two variables also demonstrate the importance of controlling for financial constraints. According to Column (2), after accounting for financial constraints, the influence of information asymmetry becomes significant and stronger. As we hypothesize, financially unconstrained firms are more likely to issue debt, while constrained firms are more likely to issue equity. This is also confirmed by the last two columns even though the coefficients of the dummies may not be significant.

Other control variables support the market timing and agency theories, while reject the trade-off theory. Consistent with market timing, firms with higher stock return in the past 12 months, higher market to book ratio, and larger stock turnover are more likely to take advantage of the equity market. If the market value is less than the book 
value of total assets, or if issuing equity will dilute the earnings price ratio, firms are less likely to issue equity, which suggests that the indicators managers care affect firms' financing choice. However, the coefficient of leverage deviation is not significant at all, which means that firms may not pay much attention to the target leverage when choosing between equity and debt. Besides, the negative coefficient of tangible assets and positive coefficient of $\mathrm{Z}$ score and stock return volatility (firm risk) may to some extent reflect the dominance of bank loans in the debt market and banks are specialized in monitoring risky firms with less collaterals but far from default. ${ }^{3}$ Finally, profitable firms tend to issue debt, while firms with high R\&D ratio tend to issue equity.

To measure the economic significance of the independent variables, we also report the elasticity of each variable. Because the double-clustering regression results cannot be used to calculate elasticity, the elasticity is obtained from the logit regression with only clustering at the firm level. It indicates the change in the probability of issuing debt for a change in each variable from minus one standard deviation to plus one standard deviation around its sample mean (or from zero to one for dummy variables) while holding other variables at their sample means. The most important two factors for issuing debt are firm size and age, which confirms our argument before that it is essential to control for these two variables. If we treat firm size and age as proxies for financial constraints as pointed out by Hadlock and Pierce (2010), this will greatly strengthen the importance of financial constraints. Next consistent with the prediction of Bolton and Freixas (2000), firm risk measured by daily stock return volatility is also important for firms' choice between equity and debt. Other papers like Helwege and Liang (1996) argue that pecking order also emphasizes that firm risk is important for security choice. In this case, the importance of firm risk is actually consistent with pecking order. The dummy for market to book ratio greater than one has an elasticity of -0.029 , which shows that managers regard stock price as an important factor when choosing whether to issue equity or debt. The unconstrained dummy is the fifth important factor for the probability of issuing debt. It is more important than

\footnotetext{
${ }^{3}$ As evidence, Holmstrom and Tirole (1997) demonstrate that monitoring is a partial substitute for collateral.
} 
profitability and tangible assets which are frequently discussed as crucial factors for issuing debt. The constrained dummy is as important as stock return and market to book ratio which are usually considered to link to the market timing behavior, while analyst coverage is as important as share turnover.

[Insert Table 8 here]

To directly compare firms choosing different financing instruments, we use the multinomial logistic regression. Table 8 shows the regression results using firms issuing SEO as the base outcome. The first regression does not control for financial constraints while the second one controls for the payout ratio decile. First, controlling for financial constraints strengthens the effect of information asymmetry. In the first regression, compared with firms issuing SEO, firms with more analyst coverage are more likely to issue private equity, but only marginally less likely to borrow bank loan. After including the payout ratio decile, as analyst coverage increases, firms are significantly less likely to borrow bank loan. Although the coefficient for firms issuing public bond is not significantly negative due to the endogeneity problem, the positive coefficient for private equity and negative coefficient for bank loan fully substantiate the pecking order theory. Second, as expected, unconstrained firms (firms in higher payout ratio deciles) are more likely to issue debt. Next, the results for other control variables are basically consistent with those in the logit regression above. Market timing theory is supported as firms with high stock return and turnover are less likely to issue private equity, and much less likely to borrow bank loan or public bond. Agency theory is also confirmed as firms with high market to book ratio are less likely to borrow bank loan, while firms will issue debt if the earnings price ratio is diluted by issuing equity. The trade-off theory is still not supported as the leverage deviation is only marginally significant for firms issuing private equity and insignificant for other firms. Other results are as follows. Compared with firms issuing SEO, smaller firms tend to issue private equity, while larger firms tend to issue debt. Firms issuing private equity and debt seem to be older than firms issuing SEO. Less profitable firms tend to issue private equity, while more profitable firms tend to borrow bank loan. Firms borrowing bank loan have lower tangible assets, 
while firms having an S\&P rating tend to issue public bond. Public bond issuers tend to have higher asset growth rate. Firms with high R\&D ratio are less likely to issue private equity and even less likely to issue debt. Private security (including private equity and bank loan) issuers tend to be riskier, while private equity issuers also have higher default risk.

[Insert Table 9 here]

Table 9 shows the multinomial logit regression results for the other three financial constraints criteria. First, firms with more analyst coverage tend to issue private equity and are less inclined to borrow bank loan. Second, except for the KZ index, financially constrained firms are less likely to issue debt and are more likely to issue private equity. Finally, the results for other control variables are similar to Table 8 , and we will not repeat the analysis here.

\section{Conclusion}

In this paper, to respond to the challenge for the pecking order theory that small and high-growth firms which are susceptible to information asymmetry tend to issue equity, we point out that pecking order fails to consider two crucial market imperfections: credit rationing caused by information asymmetry in the debt market and the frictions from the supply side of capital. To measure the magnitude of the above two problems, we use financial constraints. That is because financial constraints represent the difference in the costs between internal and external finance, and firms with higher external financing cost are more likely to face credit rationing in the debt market and the frictions from the supply side of capital. Therefore, we argue that since small and high-growth firms are inclined to be financially constrained, their tendency to issue equity mainly reflects their financial constraints rather than refutes pecking order.

To test our argument, we first show that financial constraints are different from debt capacity proposed by Lemmon and Zender (2010). We find that financially unconstrained firms are more likely to be concerned about debt capacity than constrained firm, which means that financial constraints and debt capacity represent 
different things. This is consistent with our argument because unconstrained firms are free to issue debt and thus have a higher probability of reaching debt capacity, while constrained firms cannot issue debt before they can access the debt market, and thus have a lower probability of reaching debt capacity.

Next we use the logit and multinomial logit regressions to analyze what determines firms' financing choice. First of all, to compare with prior studies, we use the logit regression to examine firms' choice between debt and equity. We find that the influence of information asymmetry is stronger after controlling for financial constraints, and financially unconstrained firms tend to issue debt while constrained firms tend to issue equity. Second, we use the multinomial logit regression to examine firms' choice among private equity, SEO, bank loan and public bond. We focus on the four financing instruments because they are the main tools to raise a substantial amount of funds. Consistent with the logit regression results, firms are more likely to follow pecking order after including the financial constraints measure, and constrained firms are more likely to issue private equity but less likely to issue debt. Besides, we find evidence in favor of the market timing theory and agency theory, but little evidence supporting the trade-off theory.

Overall, it is essential to control for financial constraints to test pecking order. However, there is no consensus what the perfect measure of financial constraints is. Further research can refine the measurement of financial constraints and see whether the impact of financial constraints on firms' financing decision is larger than what we have found here. 


\section{Appendix A}

\section{Measures of Financial Constraints}

First, following Almeida, Campello and Weisbach (2004), the payout ratio is calculated as

Payout $=($ Dividends + Repurchases $) /$ Operating Income, where Dividends is measured by Item 127 (cash dividends), Repurchases by Item 115 (purchase of common and preferred stock), and Operating Income by Item 13 (operating income before depreciation).

Second, the $\mathrm{KZ}$ index is calculated as $\mathrm{KZ}=-1.001909 \times$ Cash Flow $/ \mathrm{K}+0.2826389 \times$ Tobin's $\mathrm{Q}+3.139193 \times$ Debt/Total Capital $-39.3678 \times$ Dividends $/ \mathrm{K}-1.314759 \times \mathrm{Cash} / \mathrm{K}$,

where Cash Flow/K is computed as [Item 18 (income before extraordinary items) + Item 14 (depreciation and amortization)]/Item 8 (property, plant and equipment), Tobin's Q as [Item 181 (total liabilities) -Item 35 (deferred taxes and investment tax credit) + Item 10 (preferred stock liquidating value) + CRSP fiscal year-end market equity]/ Item 6 (total assets), with Item 56 (preferred stock redemption value) or Item 130 (preferred stock) being used whenever Item 10 is missing, Debt/Total Capital as [Item 9 (total long-term debt) + Item 34 (total debt in current liabilities)]/[Item $9+$ Item $34+$ Item 216 (total stockholders' equity)], Dividends/K as [Item 21 (dividends common) + Item 19 (dividends preferred)]/Item 8, and Cash/K as Item 1 (cash and short-term investments)/ Item 8 . Data Item 8 is lagged one period relative to other variables. In this paper, the calculation of Tobin's Q is a bit different from Lamont et al. (2001) as we follow Fama and French (2002), and we do not think this minor change will affect our results.

Third, the WW index is calculated as

$\mathrm{WW}=-0.091 \mathrm{CF}-0.062 \mathrm{DIVPOS}+0.021 \mathrm{TLTD}-0.044 \mathrm{LNTA}+0.102 \mathrm{ISG}-0.035 \mathrm{SG}$ where $\mathrm{CF}$ is computed as (Item 18 (income before extraordinary items) +Item 14 (depreciation and amortization))/Item 6 (total assets), DIVPOS equals one if Item 
127 (cash dividends) is greater than 0 and zero otherwise, TLTD is computed as (Item 9 (total long-term debt) + Item 34 (total debt in current liabilities))/Item 6, LNTA as $\log \left(\right.$ Item $6 \times$ GDP deflator), ISG as $\frac{\left(3 \text {-digit industry sales }{ }_{\mathrm{t}}-3 \text {-digit industry sales } \mathrm{t}_{\mathrm{t}-1} \text { ) }\right.}{3 \text { - } \text {-digit industry sales }_{\mathrm{t}-1}}$, and $\mathrm{SG}$ as $\frac{\left(\text { Item } 12_{\mathrm{t}} \text { (sales) } \times \mathrm{GDP} \text { deflator } \mathrm{t}_{\mathrm{t}} \text { Item } 12_{\mathrm{t}-1} \times \mathrm{GDP} \text { deflator } \mathrm{t}_{\mathrm{t}-1}\right)}{\text { Item } 12_{\mathrm{t}-1} \times \mathrm{GDP} \text { deflator }}$. According to Whited and $\mathrm{Wu}$ (2006), all variables should be deflated by the replacement cost of total assets. For simplicity, here we deflate all variables by the inflation-adjusted total assets, and this adjustment does not affect the main results.

Fourth, the SA index is calculated as $\mathrm{SA}=-0.737 \times \mathrm{Size}+0.043 \times \mathrm{Size}^{2}-0.040 \times$ Age where Size equals the natural log of inflation-adjusted total assets, Age is the number of years the firm has been on Compustat with a non-missing stock price, and Size and Age have a upper bond of $\log (\$ 4.5$ billion $)$ and 37 years, respectively. Here we convert the total assets to 2005 dollars rather than 2004 dollars in Hadlock and Pierce (2010), because the latest real GDP series available are calculated in terms of 2005 dollars, and this minor change does not change the main results.

\section{Appendix B}

\section{Estimation of the Optimal Leverage}

The partial-adjustment model in Flannery and Rangan (2006) is $\operatorname{MDR}_{i, t+1}=(\lambda \beta) X_{i, t}+(1-\lambda) M_{i, t}+\delta_{i, t+1}$, where MDR is the market leverage, the lagged X variables determine a firm's long-run target leverage.

Specifically, the lagged $\mathrm{X}$ variables include:

Profitability: earnings before interest and taxes (Item 13) to total assets (Item 6);

M/B ratio: the market-to-book ratio, same as Tobin's $\mathrm{Q}$ used in calculating $\mathrm{KZ}$ index;

Depreciation: depreciation and amortization (Item 14) to total assets;

Firm size: natural log of inflation-adjusted total assets;

Tangible assets: total property, plant and equipment (Item 8) to total assets;

R\&D ratio: $R \& D$ expense (Item 46 ) to total assets; 
R\&D dummy: equals one if a firm has zero or missing R\&D expense. This definition follows Fama and French (2002), and is a bid different from Flannery and Rangan (2006)'s definition, but the results are not affected;

Industry median leverage: the median leverage of the firm industry using Fama and French 1997 49-industry definitions for each year;

S\&P rating: equals one if the firm has a public debt rating in Compustat and zero otherwise.

We also try to include the before-financing marginal tax rate simulated as in Graham and Mills (2008) in the regression, and consistent with the tradeoff theory, it is significant at the 1 percent level. However, because the sample is greatly reduced to include this tax rate, we follow Flannery and Rangan (2006) to exclude it.

\section{Appendix C \\ Definition of Control Variables}

Firm size, $M / B$ ratio, Tangible assets, $R \& D$ ratio, $R \& D$ dummy, and $S \& P$ rating are the same as in Appendix B. The other control variables are as follows:

Log of Age: the natural log of the number of years the firm has been on Compustat with a non-missing stock price;

Leverage deviation: actual market leverage- target leverage estimated according to Appendix B;

Three-year mean ROA: the average of EBITDA/Assets (Item 13/Item 6) in the latest three fiscal years before the issue;

Net operating loss carry forwards: Tax loss carry forward/Assets (Item 52/Item 6);

One-year stock return: the cumulative stock return in the 12 months before the fiscal year end;

Dummy for $\mathbf{M} / \mathbf{B}>\mathbf{1}$ : equals one if $\mathrm{M} / \mathrm{B}$ ratio is greater than one and zero otherwise;

Dilution dummy: equals one if one minus the assumed tax rate (34\% here) times yield on Moody's Baa rated debt was less than a firm's after tax earnings-price ratio and zero otherwise as in Hovakimian et al. (2001);

Fraction of debt due in three years (FD3): [Item 44 (long-term debt due in one year) + Item 91 (debt due in 2nd year) + Item 92 (debt due in 3rd year)]/Item 142 (total 
long-term debt);

Loss dummy: equals one if Item 13 (operating income before depreciation) is negative and zero otherwise;

\section{Asset growth rate:}

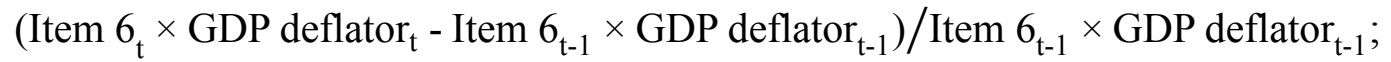

Share turnover: the median value of the monthly trading volume divided by shares outstanding over a 12-month period;

Z-score:3.3 $\times($ Item $18+$ Item $15+$ Item 16 (total income taxes) $)+$ Item 12

$$
+1.4 \times \text { Item } 36(\text { retained earnings })+1.2 \times(\text { Item } 4 \text { - Item 5)) }(\text { Item 6), }
$$

as unlevered Z-score introduced by MacKie-Mason (1990);

Stock return volatility: the standard deviation of daily stock returns in the latest fiscal year.

As in Hovakimian et al. (2001), we also try to include Net operating loss carry forwards, FD3 and the interaction of Loss dummy and FD3 in the regression, but we find they are not significant. Because it reduces the number of observations a great deal to include them, we do not report them in the main results. 


\section{References}

Agca, Senary, and Abon Mozumdar, 2007, Corporate Financing Choices Constrained by the Amount of Debt Firms Can Support, George Washington University and Virginia Tech Working Paper.

Almeida, Heitor, Murillo Campello, and Michael S. Weisbach, 2004, The Cash Flow Sensitivity of Cash, Journal of Finance 59, 1777-1804.

Baker, Malcolm P., 2009, Capital Market-Driven Corporate Finance, Annual Review of Financial Economics 1, 181-205.

Bharath, Sreedhar T., Paolo Pasquariello, and Guojun Wu, 2009, Does Asymmetric Information Drive Capital Structure Decisions? Review of Financial Studies 22, 3211-3243.

Bolton, Patrick, and Xavier Freixas, 2000, Equity, Bonds, and Bank Debt: Capital Structure and Financial Market Equilibrium under Asymmetric Information, Journal of Political Economy 108, 324-351.

Chang, Xin, Sudipto Dasgupta, and Gilles Hilary, 2006, Analyst Coverage and Financing Decisions, Journal of Finance 61, 3009-3048.

Chava, Sudheer, and Michael R. Roberts, 2008, How Does Financing Impact Investment? The Role of Debt Covenants, Journal of Finance 63, 2085-2121.

Devos, Erik, Upinder Dhillon, Murali Jagannathan, and Srinivasan Krishnamurthy, 2012, Why are firms unlevered? Journal of Corporate Finance 18, 664-682.

Erel, Isil, Brandon Julio, Woojin Kim, and Michael S. Weisbach, 2012, Macroeconomic Conditions and Capital Raising, Review of Financial Studies 25, 341-376.

Fama, Eugene F., and Kenneth R. French, 2001, Disappearing dividends: changing firm characteristics or lower propensity to pay? Journal of Financial Economics $60,3-43$.

Fama, Eugene F., and Kenneth R. French, 2002, Testing trade-off and pecking order predictions about dividends and debt, Review of Financial Studies 15, 1-33.

Fama, Eugene F., and Kenneth R. French, 2005, Financing decisions: who issues stock? Journal of Financial Economics 76, 549-582.

Fazzari, Steven M., R. Glenn Hubbard, and Bruce C. Petersen, 1988, Financing 
Constraints and Corporate Investment, Brookings Papers on Economic Activity, 141-206.

Fazzari, Steven M., and Bruce C. Petersen, 1993, Working Capital and Fixed Investment: New Evidence on Financing Constraints, RAND Journal of Economics 24, 328-342.

Flannery, Mark J., and Kasturi P. Rangan, 2006, Partial adjustment toward target capital structures, Journal of Financial Economics 79, 469-506.

Frank, Murray Z., and Vidhan K. Goyal, 2003, Testing the pecking order theory of capital structure, Journal of Financial Economics 67, 217-248.

Frank, Murray Z., and Vidhan K. Goyal, 2009, Capital structure decisions: Which factors are reliably important? Financial Management 38, 1-37.

Gomes, Armando, and Gordon Phillips, 2012, Why do public firms issue private and public securities? Journal of Financial Intermediation 21, 619-658.

Graham, John R., 2000, How Big Are the Tax Benefits of Debt? Journal of Finance $55,1901-1941$.

Graham, John R., and Lillian F. Mills, 2008, Using tax return data to simulate corporate marginal tax rates, Journal of Accounting and Economics 46, 366-388.

Hadlock, Charles J., and Joshua R. Pierce, 2010, New Evidence on Measuring Financial Constraints: Moving Beyond the KZ Index, Review of Financial Studies 23, 1909-1940.

Halov, Nikolay, and Florian Heider, 2011, Capital structure, risk and asymmetric information, Working paper.

Helwege, Jean, and Nellie Liang, 1996, Is there a pecking order? Evidence from a panel of IPO firms, Journal of Financial Economics 40, 429-458.

Holmstrom Bengt, and Jean Tirole, 1997, Financial Intermediation, Loanable Funds, and the Real Sector, Quarterly Journal of Economics 112, 663-691.

Hovakimian, Armen, Tim Opler, and Sheridan Titman, 2001, The Debt-Equity Choice, Journal of Financial and Quantitative Analysis 36, 1-24.

Jaffee, Dwight M., and Thomas Russell, 1976, Imperfect Information, Uncertainty, and Credit Rationing, Quarterly Journal of Economics 90, 651-666. 
Jung, Kooyul, Yong-Cheol Kim, and Rene Stulz, 1996, Timing, Investment Opportunities, Managerial Discretion, and the Security Issue Decision, Journal of Financial Economics 42, 159-185.

Kaplan, Steven N., and Luigi Zingales, 1997, Do Investment-Cash Flow Sensitivities Provide Useful Measures of Financing Constraints? Quarterly Journal of Economics 112, 169-215.

Kashyap, Anil K., Owen A. Lamont, and Jeremy C. Stein, 1994, Credit Conditions and the Cyclical Behavior of Inventories, Quarterly Journal of Economics 109, 565-592.

Korajczyk, Robert A., and Amnon Levy, 2003, Capital structure choice: macroeconomic conditions and financial constraints, Journal of Financial Economics 68, 75-109.

Lamont, Owen, Christopher Polk, and Jesus Saa-Requejo, 2001, Financial Constraints and Stock Returns, Review of Financial Studies 14, 529-554.

Leary, Mark T., and Michael R. Roberts, 2010, The pecking order, debt capacity, and information asymmetry, Journal of Financial Economics 95, 332-355.

Lemmon, Michael L., and Jaime F. Zender, 2001, Looking Under the Lamppost: An Empirical Examination of the Determinants of Capital Structure, Working paper, University of Utah.

Lemmon, Michael L., and Jaime F. Zender, 2010, Debt capacity and tests of capital structure theories, Journal of Financial and Quantitative Analysis 45, 1161-1187.

Li, Dongmei, 2011, Financial Constraints, R\&D Investment, and Stock Returns, Review of Financial Studies 24, 2974-3007.

Marsh, Paul, 1982, The choice between equity and debt: An empirical study, Journal of Finance 37, 121-144.

Minton, Bernadette A., and Karen H. Wruck, 2001, Financial Conservatism: Evidence on Capital Structure from Low Leverage Firms, Working paper, The Ohio State University.

Myers, Stewart C., 1984, The capital structure puzzle, Journal of Finance 39, $575-592$.

Myers, Stewart C., and Nicholas S. Majluf, 1984, Corporate financing and investment decisions when firms have information that investors do not have, Journal of 
Petersen, Mitchell A., 2009, Estimating Standard Errors in Finance Panel Data Sets: Comparing Approaches, Review of Financial Studies 22, 435-480.

Rajan, Raghuram G., and Luigi Zingales, 1995, What Do We Know about Capital Structure? Some Evidence from International Data, Journal of Finance 50, $1421-1460$.

Shyam-Sunder, Lakshmi, and Stewart C. Myers, 1999, Testing static tradeoff against pecking order models of capital structure, Journal of Financial Economics 51, 219-244.

Stiglitz, Joseph E., and Andrew Weiss, 1981, Credit Rationing in Markets with Imperfect Information, American Economic Review 71, 393-410.

Stiglitz, Joseph E., and Andrew Weiss, 1983, Incentive Effects of Terminations: Applications to the Credit and Labor Markets, American Economic Review 73, 912-927.

Taggart, Robert A. Jr., 1977, A Model of Corporate Financing Decisions, Journal of Finance 32, 1467-1484.

Titman, Sheridan, and Roberto Wessels, 1988, The Determinants of Capital Structure Choice, Journal of Finance 43, 1-19.

Whited, Toni M., and Guojun Wu, 2006, Financial Constraints Risk, Review of Financial Studies 19, 531-559. 


\section{Table 1}

\section{Summary Statistics}

This table reports the mean and median statistics for the whole sample and firms with different financing choices. The total sample includes all the listed firms in NYSE, Amex and Nasdaq excluding financial firms, utilities and firms with missing or zero total assets. Private equity refers to firms issuing private equity, SEO to firms issuing SEO, Loan to firms borrowing bank loan, and Bond to firms issuing public bond. The security issue data ranges from 1988 to 2008, while financial statement and other variables are the latest pre-issue data. Firm size is the natural log of total assets converted to 2005 dollars. Age is the number of years a firm was first included in Compustat with a non-missing stock price. Number of analysts is the maximum number of analysts that make annual earnings forecasts any month over a 12-month period with a 3-year lag. Payout ratio is the ratio of dividends plus repurchases to operating income. The KZ index is a linear combination of cash flow to capital, dividends to capital, and cash holdings to capital with negative coefficients, and Tobin's Q and debt to total capital with positive coefficients. The WW index is a linear combination of cash flow to total assets, dividend-paying dummy, long-term debt to total assets, log of total assets, firm's 3-digit industry sales growth, and firm's sale growth. The SA index is calculated as $-0.737 \times \mathrm{Size}+0.043 \times \mathrm{Size}^{2}-0.040 \times$ Age as in Hadlock and Pierce (2010), where Size and Age have a upper bond of $\log (\$ 4.5$ billion $)$ and 37 years, respectively. Profitability is the ratio of EBITDA to total assets. Market to book ratio is the market value of total assets divided by its book value. Dummy for $\mathrm{M} / \mathrm{B}>1$ equals one if $\mathrm{M} / \mathrm{B}$ ratio is greater than one and zero otherwise. Depreciation is depreciation divided by total assets. Tangible assets is the ratio of total net property, plant and equipment to total assets. R\&D ratio is the research and development expense divided by total sales. R\&D dummy equals one if R\&D ratio equals zero. Industry median leverage is the median leverage of the firm industry using Fama and French 199749 -industry definitions. S\&P rating dummy equals one if a firm has the S\&P domestic long term issuer credit rating (item 280) in Compustat. Book leverage is the sum of short-term debt and long-term debt divided by total assets. Market leverage is the sum of short-term debt and long-term debt divided by market value of total assets, calculated as total liabilities minus deferred taxes and investment tax credit plus liquidating value of preferred stock (redemption or book value used when unavailable) plus the product of stock price times common shares outstanding. Target leverage is the estimated optimal leverage based on Flannery and Rangan (2006). Leverage deviation is the difference between actual market leverage and target leverage. One-year stock return is the cumulative stock return in the 12 months before the fiscal year end. Dilution dummy equals one if one minus the assumed tax rate ( $34 \%$ here) times yield on Moody's Baa rated debt was less than a firm's after tax earnings-price ratio and zero otherwise as in Hovakimian et al. (2001). Asset growth rate is the growth rate of inflation-adjusted total assets in the prior fiscal year. Share turnover is the median value of the monthly trading volume divided by shares outstanding over a 12 -month period. $\mathrm{Z}$ score equals $3.3 \times($ item $18+$ item15+item 16)+item 12+1.4×item 36+1.2×(item 4-item 5))(item 6) as introduced by MacKie-Mason (1990). Stock return volatility refers to the standard deviation of a firm's daily stock returns in the prior fiscal year. Variables are winsorized at both 1 percent tails. $\mathrm{T}$ test for the mean and Wilcoxon test for the median comparing with firms issuing SEO are reported, and $* * *, * *$ and $*$ denote a significant level of 1 percent, 5 percent, and 10 percent, respectively. 


\begin{tabular}{|c|c|c|c|c|c|c|c|c|c|c|}
\hline \multirow[b]{2}{*}{ Variables } & \multicolumn{5}{|c|}{ Mean } & \multicolumn{5}{|c|}{ Median } \\
\hline & Total & Private equity & SEO & Loan & Bond & Total & Private equity & SEO & Loan & Bond \\
\hline Size & 5.60 & $4.15^{* * *}$ & 5.44 & $6.57 * * *$ & $8.16^{* * *}$ & 5.44 & $3.86^{* * *}$ & 5.23 & $6.52 * * *$ & $8.15 * * *$ \\
\hline Age & 12.64 & 7.84 & 8.31 & $15.00 * * *$ & $21.61 * * *$ & 9 & $6 * * *$ & 5 & $11 * * *$ & $24 * * *$ \\
\hline Number of analysts & 3.48 & $1.77 * * *$ & 2.86 & $4.69 * * *$ & $10.64 * * *$ & 0 & $0 * * *$ & 0 & $0 * * *$ & $8 * * *$ \\
\hline Payout ratio & 0.15 & $0.06^{* * *}$ & 0.09 & $0.17 * * *$ & $0.21 * * *$ & 0.00 & $0.00 * * *$ & 0.00 & $0.04 * * *$ & $0.12 * * *$ \\
\hline $\mathrm{KZ}$ index & -7.66 & -10.82 & -10.33 & $-3.59 * * *$ & $-2.74 * * *$ & -0.96 & $-0.45 * * *$ & -0.82 & $-0.06 * * *$ & $0.02 * * *$ \\
\hline WW index & -0.27 & $-0.18 * * *$ & -0.26 & $-0.32 * * *$ & $-0.40 * * *$ & -0.27 & $-0.17 * * *$ & -0.25 & $-0.31 * * *$ & $-0.41 * * *$ \\
\hline SA index & -3.11 & $-2.50 * * *$ & -2.95 & $-3.43 * * *$ & $-3.93 * * *$ & -3.10 & $-2.46 * * *$ & -2.91 & $-3.36 * * *$ & $-4.04 * * *$ \\
\hline Profitability & 0.08 & $-0.24 * * *$ & 0.05 & $0.13 * * *$ & $0.14 * * *$ & 0.12 & $-0.15 * * *$ & 0.11 & $0.13 * * *$ & $0.14 * * *$ \\
\hline Market to book ratio & 2.16 & $3.61 * * *$ & 2.92 & $1.80 * * *$ & $1.71 * * *$ & 1.54 & $2.54 * * *$ & 1.99 & $1.44 * * *$ & $1.42 * * *$ \\
\hline Dummy for M/B>1 & 0.84 & $0.91 * * *$ & 0.95 & $0.86^{* * *}$ & $0.88 * * *$ & 1 & $1 * * *$ & 1 & $1 * * *$ & $1 * * *$ \\
\hline Depreciation & 0.05 & $0.05 * * *$ & 0.04 & $0.05 * * *$ & $0.05 * * *$ & 0.04 & 0.04 & 0.04 & $0.04 * * *$ & $0.04 * * *$ \\
\hline Tangible assets & 0.29 & $0.24 * * *$ & 0.30 & $0.34 * * *$ & $0.40 * * *$ & 0.23 & $0.13 * * *$ & 0.21 & $0.28 * * *$ & $0.36 * * *$ \\
\hline $\mathrm{R} \& \mathrm{D}$ ratio & 0.05 & $0.18 * * *$ & 0.08 & $0.02 * * *$ & $0.01 * * *$ & 0.00 & $0.09 * * *$ & 0.00 & $0 * * *$ & $0 * * *$ \\
\hline R\&D dummy & 0.48 & $0.30 * * *$ & 0.49 & $0.61 * * *$ & $0.60 * * *$ & 0 & $0 * * *$ & 0 & $1 * * *$ & $1 * * *$ \\
\hline Industry median leverage & 0.12 & $0.07 * * *$ & 0.11 & $0.14 * * *$ & $0.16^{* * *}$ & 0.12 & $0.03 * * *$ & 0.11 & $0.14 * * *$ & $0.16^{* * *}$ \\
\hline S\&P rating dummy & 0.24 & $0.08 * * *$ & 0.22 & $0.41 * * *$ & $0.85 * * *$ & 0 & $0 * * *$ & 0 & $0 * * *$ & $1 * * *$ \\
\hline Book leverage & 0.21 & $0.19 * * *$ & 0.25 & $0.28 * * *$ & $0.35 * * *$ & 0.17 & $0.10 * * *$ & 0.20 & $0.26 * * *$ & $0.32 * * *$ \\
\hline Market leverage & 0.16 & $0.10 * * *$ & 0.16 & $0.21 * * *$ & $0.25 * * *$ & 0.10 & $0.04 * * *$ & 0.10 & $0.18 * * *$ & $0.22 * * *$ \\
\hline Target leverage & 0.23 & $0.17 * * *$ & 0.23 & $0.29 * * *$ & $0.38 * * *$ & 0.22 & $0.15 * * *$ & 0.21 & $0.28 * * *$ & $0.38 * * *$ \\
\hline Leverage deviation (actual-target) & -0.08 & -0.06 & -0.07 & -0.08 & $-0.13 * * *$ & -0.11 & $-0.09 * * *$ & -0.11 & $-0.11 * * *$ & $-0.16 * * *$ \\
\hline Firm stock return & 0.18 & $0.29 * * *$ & 0.46 & $0.21 * * *$ & $0.19 * * *$ & 0.14 & $0.22 * * *$ & 0.37 & $0.18 * * *$ & $0.17 * * *$ \\
\hline Dilution dummy & 0.37 & $0.13 * * *$ & 0.24 & $0.44 * * *$ & $0.49 * * *$ & 0 & $0 * * *$ & 0 & $0 * * *$ & $0 * * *$ \\
\hline Asset growth rate & 0.28 & $0.40 * * *$ & 0.62 & $0.24 * * *$ & $0.20 * * *$ & 0.06 & $0.07 * * *$ & 0.21 & $0.07 * * *$ & $0.06 * * *$ \\
\hline Share turnover & 0.01 & $0.01 *$ & 0.02 & $0.01 * * *$ & $0.01 * * *$ & 0.01 & $0.01 * *$ & 0.01 & $0.01 * * *$ & $0.01 * * *$ \\
\hline Z-score & 1.29 & $-3.09 * * *$ & 0.81 & $1.76^{* * *}$ & $1.64 * * *$ & 1.80 & $-1.76 * * *$ & 1.32 & $1.85 * * *$ & $1.60 * * *$ \\
\hline Stock return volatility & 0.03 & $0.05 * * *$ & 0.04 & $0.03 * * *$ & $0.02 * * *$ & 0.03 & $0.04 * * *$ & 0.03 & $0.03 * * *$ & $0.02 * * *$ \\
\hline Number of observations & 69411 & 984 & 2861 & 14499 & 3180 & 69411 & 984 & 2861 & 14499 & 3180 \\
\hline
\end{tabular}


Table 2

Distribution of Security Issues by Year

This table shows the distribution of each type of security issues across years from 1988 to 2008 . Here we aggregate the same type of security issued by the same firm in one fiscal year as one observation as one issuance may have several tranches. The first four columns show the number of firms issuing private equity, SEO, loan and bond, respectively, while the last column shows the total number of firms in each year.

\begin{tabular}{cccccc} 
Year & Private equity & SEO & Loan & Bond & Total \\
\hline 1988 & 7 & 35 & 319 & 54 & 2515 \\
1989 & 14 & 54 & 348 & 59 & 2471 \\
1990 & 16 & 47 & 384 & 52 & 2501 \\
1991 & 7 & 148 & 382 & 94 & 2582 \\
1992 & 17 & 121 & 465 & 123 & 2737 \\
1993 & 15 & 178 & 493 & 143 & 2955 \\
1994 & 7 & 123 & 696 & 74 & 3172 \\
1995 & 12 & 162 & 675 & 127 & 3307 \\
1996 & 10 & 236 & 811 & 140 & 3534 \\
1997 & 14 & 190 & 960 & 194 & 3773 \\
1998 & 5 & 133 & 785 & 232 & 3769 \\
1999 & 17 & 144 & 720 & 180 & 3649 \\
2000 & 32 & 164 & 745 & 105 & 3675 \\
2001 & 89 & 129 & 831 & 214 & 3738 \\
2002 & 102 & 127 & 844 & 201 & 3708 \\
2003 & 114 & 159 & 800 & 245 & 3656 \\
2004 & 119 & 184 & 977 & 241 & 3576 \\
2005 & 81 & 146 & 986 & 193 & 3548 \\
2006 & 97 & 138 & 906 & 181 & 3508 \\
2007 & 113 & 147 & 814 & 186 & 3481 \\
2008 & 96 & 96 & 558 & 142 & 3556 \\
\hline Total & 984 & 2861 & 14499 & 3180 & 69411 \\
\hline
\end{tabular}


Table 3

\section{Comparison of the Four Financial Constraints Measures}

This table compares the four financial constraints measures. Definitions of the criteria can be found in Table 1. Panel A shows the correlation matrix between the constrained and unconstrained firms based on any two of the criteria. Panel B shows the key firm characteristics for the constrained and unconstrained firms defined by each measure.

Panel A Correlation between financial constraints criteria

\begin{tabular}{|c|c|c|c|c|c|c|c|c|c|}
\hline $\begin{array}{l}\text { Financial } \\
\text { constraints criteria }\end{array}$ & & $\underline{\text { Payou }}$ & ratio & $\underline{\mathbf{K Z}}$ & idex & $\underline{\mathbf{W W}}$ & ndex & $\underline{\mathbf{S A}}$ & Idex \\
\hline Payout ratio & & $\underline{\mathrm{C}}$ & $\underline{U}$ & $\underline{\mathrm{C}}$ & $\underline{\mathrm{U}}$ & $\underline{\mathrm{C}}$ & $\underline{\mathrm{U}}$ & $\underline{\mathrm{C}}$ & $\underline{\mathrm{U}}$ \\
\hline Constrained firms & $\mathrm{C}$ & 33,756 & & & & & & & \\
\hline Unconstrained firms & $\mathrm{U}$ & & 20,807 & & & & & & \\
\hline $\mathrm{KZ}$ index & & & & & & & & & \\
\hline Constrained firms & $\mathrm{C}$ & 12,538 & 2,750 & 20,493 & & & & & \\
\hline Unconstrained firms & $\mathrm{U}$ & 9,572 & 8,286 & & 20,512 & & & & \\
\hline WW index & & & & & & & & & \\
\hline Constrained firms & $\mathrm{C}$ & 16,376 & 2,050 & 6,911 & 6,228 & 20,265 & & & \\
\hline Unconstrained firms & $\mathrm{U}$ & 2,563 & 11,062 & 5,044 & 5,472 & & 20,282 & & \\
\hline SA index & & & & & & & & & \\
\hline Constrained firms & $\mathrm{C}$ & 16,138 & 2,517 & 5,381 & 8,255 & 14,970 & 404 & 20,730 & \\
\hline Unconstrained firms & $\mathrm{U}$ & 3,957 & 10,710 & 5,592 & 5,066 & 522 & 13,883 & & 20,755 \\
\hline
\end{tabular}

Panel B Key firm characteristics based on each financial constraints criterion

Mean

\begin{tabular}{|c|c|c|c|c|c|c|c|c|}
\hline \multirow{2}{*}{$\begin{array}{l}\text { Financial } \\
\text { constraints criteria }\end{array}$} & \multicolumn{2}{|c|}{$\underline{\text { Payout ratio }}$} & \multicolumn{2}{|c|}{$\underline{\mathrm{KZ} \text { index }}$} & \multicolumn{2}{|c|}{$\underline{\text { WW index }}$} & \multicolumn{2}{|c|}{$\underline{\text { SA index }}$} \\
\hline & $\underline{\mathrm{C}}$ & $\underline{\mathrm{U}}$ & $\underline{\mathrm{C}}$ & $\underline{\mathrm{U}}$ & $\underline{\mathrm{C}}$ & $\underline{\mathrm{U}}$ & $\underline{\mathrm{C}}$ & $\underline{\mathrm{U}}$ \\
\hline Analyst coverage & 1.73 & 6.10 & 2.66 & 3.31 & 0.72 & 7.63 & 0.48 & 7.70 \\
\hline Tangible assets & 0.25 & 0.32 & 0.43 & 0.13 & 0.22 & 0.37 & 0.22 & 0.34 \\
\hline S\&P rating & 0.12 & 0.36 & 0.31 & 0.14 & 0.01 & 0.59 & 0.00 & 0.54 \\
\hline Private equity & $2.47 \%$ & $0.41 \%$ & $1.88 \%$ & $1.40 \%$ & $2.96 \%$ & $0.54 \%$ & $3.37 \%$ & $0.34 \%$ \\
\hline SEO & $5.45 \%$ & $2.24 \%$ & $4.78 \%$ & $4.41 \%$ & $3.94 \%$ & $3.05 \%$ & $5.20 \%$ & $2.58 \%$ \\
\hline Loan & $16.36 \%$ & $24.29 \%$ & $27.53 \%$ & $13.08 \%$ & $10.20 \%$ & $30.91 \%$ & $9.45 \%$ & $29.85 \%$ \\
\hline \multirow[t]{3}{*}{ Bond } & $2.05 \%$ & $7.49 \%$ & $6.44 \%$ & $2.67 \%$ & $0.19 \%$ & $12.03 \%$ & $0.13 \%$ & $10.97 \%$ \\
\hline & \multicolumn{8}{|c|}{ Median } \\
\hline & $\underline{\mathrm{C}}$ & $\underline{\mathrm{U}}$ & $\underline{\mathrm{C}}$ & $\underline{\mathrm{U}}$ & $\underline{\mathrm{C}}$ & $\underline{\mathrm{U}}$ & $\underline{\mathrm{C}}$ & $\underline{\mathrm{U}}$ \\
\hline Analyst coverage & 0 & 2 & 0 & 0 & 0 & 4 & 0 & 4 \\
\hline Tangible assets & 0.17 & 0.27 & 0.40 & 0.09 & 0.15 & 0.32 & 0.14 & 0.29 \\
\hline S\&P rating & 0 & 0 & $\mathbf{0}$ & $\mathbf{0}$ & 0 & 1 & 0 & 1 \\
\hline
\end{tabular}




\section{Table 4}

\section{Comparison of New Security Issues Data with the Compustat Data}

This table compares the type of security issued based on new security issues data with the type of security issued based on the inference from the Compustat data. According to Hovakimian et al. (2001), a firm issues equity (debt) if its new equity (debt) issues exceed 5 percent of total assets. In Panel A, we include the private equity and SEO issued based on new security issues data to compare with the new equity issues in the Compustat. In Panel B, we include the bank loan and public bond issued based on new security issues data to compare with the new debt issues in the Compustat.

Panel A New equity issues

\section{Compustat data}

Net equity issues $>5 \%$

\begin{tabular}{llccc}
\cline { 3 - 5 } New security issues data & & Total & No & Yes \\
\hline Private equity & Total & 69,411 & 58,800 & 10,611 \\
\cline { 2 - 5 } & Nonissuer & 68,427 & 58,660 & 9,767 \\
& Issuer & 984 & 140 & 844 \\
\hline \multirow{2}{*}{ SEO } & Total & 69,411 & 58,800 & 10,611 \\
\cline { 2 - 5 } & Nonissuer & 66,550 & 58,525 & 8,025 \\
& Issuer & 2,861 & 275 & 2,586 \\
\hline
\end{tabular}

Panel B New debt issues

\begin{tabular}{llccc} 
& & \multicolumn{3}{c}{ Net debt issues $>\mathbf{5 \%}$} \\
\cline { 3 - 5 } Loan & Total & Total & No & Yes \\
\cline { 2 - 4 } & Nonissuer & 59,411 & 56,271 & 13,140 \\
\hline \multirow{2}{*}{ Bond } & Issuer & 14,4912 & 46,932 & 7,980 \\
& Total & 69,411 & 9,339 & 5,160 \\
\cline { 2 - 4 } & Nonissuer & 66,231 & 56,271 & 13,140 \\
\hline & Issuer & 3,180 & 54,569 & 11,662 \\
& & & 1,702 & 1,478 \\
\hline
\end{tabular}




\section{Table 5}

\section{Estimates of Target Leverage}

This table shows the regression results of the partial-adjustment model as Table 2 in Flannery and Rangan (2006). Here FM stands for the Fama and MacBeth (1973) regression, FE panel refers to the fixed effects model of panel data, FE panel with year dummy adds year dummy to FE panel, IV panel substitutes fitted value from instrumental variable regression for market leverage compared with FE panel with year dummy, and Base specification includes S\&P rating in the main regression equation relative to IV panel. T-statistics are shown in parentheses. ${ }^{* *},{ }^{* *}$ and $*$ denote a significant level of 1 percent, 5 percent, and 10 percent, respectively.

(1)

(2)

(3)

(4)

(5)

\begin{tabular}{|c|c|c|c|c|c|}
\hline VARIABLES & FM & FE panel & $\begin{array}{c}\text { FE panel with } \\
\text { year dummy }\end{array}$ & IV panel & $\begin{array}{c}\text { Base } \\
\text { specification }\end{array}$ \\
\hline \multirow[t]{2}{*}{ Market leverage } & $0.847 * * *$ & $0.591 * * *$ & $0.587 * * *$ & $0.613 * * *$ & $0.610^{* * *}$ \\
\hline & $(57.297)$ & $(167.001)$ & $(169.535)$ & $(140.302)$ & (137.577) \\
\hline \multirow[t]{2}{*}{ Profitability } & $-0.014 * * *$ & $-0.030 * * *$ & $-0.035 * * *$ & $-0.031 * * *$ & $-0.031 * * *$ \\
\hline & $(-3.229)$ & $(-10.091)$ & $(-11.731)$ & $(-10.443)$ & $(-10.375)$ \\
\hline \multirow[t]{2}{*}{ Market to book ratio } & $-0.001 * *$ & 0.000 & -0.000 & 0.000 & 0.000 \\
\hline & $(-2.284)$ & $(1.541)$ & $(-0.607)$ & $(0.786)$ & $(0.553)$ \\
\hline \multirow[t]{2}{*}{ Depreciation } & $-0.123 * * *$ & $-0.155^{* * *}$ & $-0.101 * * *$ & $-0.109 * * *$ & $-0.110 * * *$ \\
\hline & $(-5.947)$ & $(-9.511)$ & $(-6.287)$ & $(-6.735)$ & $(-6.812)$ \\
\hline \multirow[t]{2}{*}{ Size } & $0.002 * * *$ & $0.016 * * *$ & $0.021 * * *$ & $0.020 * * *$ & $0.020 * * *$ \\
\hline & $(4.100)$ & $(30.819)$ & $(34.177)$ & $(32.422)$ & $(31.240)$ \\
\hline \multirow[t]{2}{*}{ Asset tangibility } & $0.025 * * *$ & $0.053 * * *$ & $0.040 * * *$ & $0.036^{* * *}$ & $0.037 * * *$ \\
\hline & $(3.649)$ & $(12.759)$ & $(9.602)$ & $(8.717)$ & $(8.904)$ \\
\hline \multirow[t]{2}{*}{ R\&D dummy } & $0.008 * * *$ & 0.003 & 0.002 & 0.002 & 0.002 \\
\hline & $(6.970)$ & $(1.276)$ & $(0.855)$ & $(0.772)$ & $(0.773)$ \\
\hline \multirow[t]{2}{*}{$\mathrm{R} \& \mathrm{D}$ ratio } & $-0.027 * * *$ & $-0.015^{*}$ & $-0.015 * *$ & -0.012 & $-0.013^{*}$ \\
\hline & $(-3.589)$ & $(-1.945)$ & $(-2.002)$ & $(-1.630)$ & $(-1.702)$ \\
\hline \multicolumn{6}{|l|}{ Industry median } \\
\hline \multirow[t]{2}{*}{ leverage } & $0.052 * * *$ & $0.122 * * *$ & $0.053 * * *$ & $0.039 * * *$ & $0.039 * * *$ \\
\hline & $(4.800)$ & $(12.559)$ & $(4.723)$ & $(3.413)$ & $(3.430)$ \\
\hline \multirow[t]{2}{*}{$\mathrm{S} \& \mathrm{P}$ rating dummy } & & & & & $0.006^{* * *}$ \\
\hline & & & & & $(3.929)$ \\
\hline \multirow[t]{2}{*}{ Constant } & $0.009^{*}$ & $-0.043 * * *$ & $-0.032 * * *$ & $-0.030 * * *$ & $-0.028 * * *$ \\
\hline & $(2.055)$ & $(-10.962)$ & $(-7.363)$ & $(-6.805)$ & $(-6.421)$ \\
\hline Fixed effects & No & Yes & Yes & Yes & Yes \\
\hline Observations & 69,411 & 69,411 & 69,411 & 69,411 & 69,411 \\
\hline R-squared & 0.761 & 0.3862 & 0.4196 & 0.419 & 0.4193 \\
\hline
\end{tabular}




\section{Table 6}

Shyam-Sunder and Myers (1999) and Lemmon and Zender (2010) Regression Results This table reports the Shyam-Sunder and Myers (1999) regression and Lemmon and Zender (2010) modified regression results for different types of firms based on the SA index. We first classify the sample into deciles based on the SA index, and then define the top (bottom) three deciles as financially constrained (unconstrained) firms, while define firms in-between as intermediate firms. Robust t-statistics clustered at both the firm and year levels are shown in parentheses. ${ }^{* * *}, * *$ and * denote a significant level of 1 percent, 5 percent, and 10 percent, respectively.

Dependent variable is Net debt issues

\section{VARIABLES}

Financing deficit

Squared financing deficit

Constant

Observations

R-squared

\section{Unconstrained firms \\ $0.723 * * *$ \\ $0.453 * * *$}

(26.873)

$-0.140 * * *$

$(-11.401)$

$0.010 * * *$

(4.799)

19,811

(17.143)

0.670

$0.012 * * *$

(5.113)

19,811

0.538
Intermediate firms

$0.429 * * *$

(15.287)

$-0.077 * * *$

$(-15.382)$

0.000

$0.138 * * *$

Constrained firms

$$
\text { (5.167) }
$$

(5.937)

$-0.012 * * *$

(0.113)

$0.019 * * * \quad-0.007 * * *$

0.000

26,395

(4.619)

$(-4.498)$

$(0.126)$

0.381

26,395

19,695

19,695

0.195

0.035

0.016


Table 7

\section{Logit Regression of Firms' Choice between Debt and Equity}

This table reports the logit regression results of firms' choice between debt and equity. The sample is firms that only issue one type of security in the next fiscal year. The constrained (unconstrained) dummy equals one if a firm is in the top (bottom) three deciles of being financially constrained based on each financial constraints measure. The first column does not include the unconstrained and constrained dummies, while the last four columns include the unconstrained and constrained dummies based on one of the four criteria. Elasticity indicates the change in the probability of issuing debt for a change in an independent variable from minus one standard deviation to plus one standard deviation around its sample mean (or from zero to one for dummy variables) holding other variables at their sample means. Here elasticity is obtained for the payout ratio regression only clustering at the firm level, as the double clustering regression cannot calculate marginal effects. Robust t-statistics clustered at both the firm and year levels are shown in parentheses. ***, ** and $*$ denote a significant level of 1 percent, 5 percent, and 10 percent, respectively.

\begin{tabular}{|c|c|c|c|c|c|c|}
\hline VARIABLES & (1) & $\begin{array}{l}\text { Payout } \\
\text { ratio } \\
(2) \\
\end{array}$ & Elasticity & $\begin{array}{c}\text { The KZ } \\
\text { index } \\
\text { (3) }\end{array}$ & $\begin{array}{c}\text { The WW } \\
\text { index } \\
(4)\end{array}$ & $\begin{array}{c}\text { The SA } \\
\text { index } \\
(5)\end{array}$ \\
\hline Analyst coverage & $\begin{array}{l}-0.014 * \\
(-1.858)\end{array}$ & $\begin{array}{l}-0.018 * * \\
(-2.470)\end{array}$ & -0.008 & $\begin{array}{l}-0.013 * \\
(-1.836)\end{array}$ & $\begin{array}{l}-0.014^{*} \\
(-1.808)\end{array}$ & $\begin{array}{c}-0.012 \\
(-1.590)\end{array}$ \\
\hline Unconstrained dummy & & $\begin{array}{c}0.749 * * * \\
(5.283)\end{array}$ & 0.020 & $\begin{array}{l}-0.251 * * \\
(-2.137)\end{array}$ & $\begin{array}{c}0.331 * * * \\
(2.852)\end{array}$ & $\begin{array}{c}0.270 \\
(1.604)\end{array}$ \\
\hline Constrained dummy & & $\begin{array}{c}-0.310^{* * *} \\
(-3.502)\end{array}$ & -0.011 & $\begin{array}{c}0.055 \\
(0.534)\end{array}$ & $\begin{array}{c}-0.070 \\
(-0.608)\end{array}$ & $\begin{array}{c}-0.154 \\
(-1.218)\end{array}$ \\
\hline Firm size & $\begin{array}{c}0.392 * * * \\
(8.315)\end{array}$ & $\begin{array}{c}0.359 * * * \\
(8.018)\end{array}$ & 0.181 & $\begin{array}{c}0.385 * * * \\
(8.147)\end{array}$ & $\begin{array}{c}0.339 * * * \\
(7.039)\end{array}$ & $\begin{array}{c}0.335^{* * *} \\
(5.646)\end{array}$ \\
\hline $\log ($ Age $)$ & $\begin{array}{c}0.257 * * * \\
(6.573)\end{array}$ & $\begin{array}{c}0.202 * * * \\
(5.050)\end{array}$ & 0.038 & $\begin{array}{c}0.253 * * * \\
(6.433)\end{array}$ & $\begin{array}{c}0.245^{* * *} \\
(6.301)\end{array}$ & $\begin{array}{c}0.182 * * * \\
(2.930)\end{array}$ \\
\hline $\begin{array}{l}\text { Leverage deviation } \\
\text { (actual-target) }\end{array}$ & $\begin{array}{l}-0.070 \\
(-0.198)\end{array}$ & $\begin{array}{l}0.145 \\
(0.397)\end{array}$ & -0.001 & $\begin{array}{l}-0.255 \\
(-0.617)\end{array}$ & $\begin{array}{l}0.026 \\
(0.072)\end{array}$ & $\begin{array}{l}-0.074 \\
(-0.200)\end{array}$ \\
\hline Three-year mean ROA & $\begin{array}{c}2.472^{* * *} \\
(6.003)\end{array}$ & $\begin{array}{c}2.220^{* * *} \\
(5.492)\end{array}$ & 0.019 & $\begin{array}{c}2.438^{* * *} \\
(5.959)\end{array}$ & $\begin{array}{c}2.521^{* * *} \\
(6.169)\end{array}$ & $\begin{array}{c}2.495 * * * \\
(6.065)\end{array}$ \\
\hline One-year stock return & $\begin{array}{c}-0.703 * * * \\
(-7.996)\end{array}$ & $\begin{array}{c}-0.652 * * * \\
(-8.109)\end{array}$ & -0.012 & $\begin{array}{c}-0.712^{* * *} \\
(-8.182)\end{array}$ & $\begin{array}{c}-0.692 * * * \\
(-7.881)\end{array}$ & $\begin{array}{c}-0.697 * * * \\
(-7.912)\end{array}$ \\
\hline Market-to-book ratio & $\begin{array}{l}-0.058 * * \\
(-2.346)\end{array}$ & $\begin{array}{c}-0.067 * * * \\
(-2.757)\end{array}$ & -0.011 & $\begin{array}{l}-0.052 * * \\
(-2.113)\end{array}$ & $\begin{array}{c}-0.066^{* * *} \\
(-2.588)\end{array}$ & $\begin{array}{l}-0.058 * * \\
(-2.348)\end{array}$ \\
\hline Dummy for $M / B>1$ & $\begin{array}{c}-0.416^{* * *} \\
(-5.504)\end{array}$ & $\begin{array}{c}-0.418^{* * *} \\
(-5.801)\end{array}$ & -0.029 & $\begin{array}{c}-0.420 * * * \\
(-5.325)\end{array}$ & $\begin{array}{c}-0.415 * * * \\
(-5.584)\end{array}$ & $\begin{array}{c}-0.421 * * * \\
(-5.724)\end{array}$ \\
\hline Dilution dummy & $\begin{array}{c}0.499 * * * \\
(6.895)\end{array}$ & $\begin{array}{c}0.442 * * * \\
(6.053)\end{array}$ & 0.015 & $\begin{array}{c}0.514 * * * \\
(7.075)\end{array}$ & $\begin{array}{c}0.479 * * * \\
(6.603)\end{array}$ & $\begin{array}{c}0.497 * * * \\
(6.867)\end{array}$ \\
\hline Tangible assets & $\begin{array}{c}-0.686^{* * *} \\
(-3.053)\end{array}$ & $\begin{array}{c}-0.663 * * * \\
(-2.952)\end{array}$ & -0.017 & $\begin{array}{c}-0.889 * * * \\
(-3.718)\end{array}$ & $\begin{array}{c}-0.712 * * * \\
(-3.204)\end{array}$ & $\begin{array}{c}-0.688 * * * \\
(-3.061)\end{array}$ \\
\hline $\mathrm{S} \& \mathrm{P}$ rating dummy & $\begin{array}{c}0.154 \\
(0.899)\end{array}$ & $\begin{array}{c}0.158 \\
(0.926)\end{array}$ & 0.005 & $\begin{array}{c}0.159 \\
(0.921)\end{array}$ & $\begin{array}{c}0.113 \\
(0.691)\end{array}$ & $\begin{array}{c}0.167 \\
(0.950)\end{array}$ \\
\hline
\end{tabular}




\begin{tabular}{lcccccc} 
Asset growth rate & -0.087 & -0.068 & -0.001 & -0.059 & -0.103 & -0.089 \\
& $(-1.031)$ & $(-0.780)$ & & $(-0.692)$ & $(-1.176)$ & $(-1.047)$ \\
R\&D ratio & $-4.228^{* * *}$ & $-4.058^{* * *}$ & -0.014 & $-4.175^{* * *}$ & $-4.148^{* * *}$ & $-4.229^{* * *}$ \\
& $(-6.825)$ & $(-6.637)$ & & $(-6.871)$ & $(-6.846)$ & $(-6.825)$ \\
R\&D dummy & 0.111 & $0.138^{*}$ & 0.006 & 0.108 & 0.118 & 0.109 \\
& $(1.347)$ & $(1.657)$ & & $(1.307)$ & $(1.412)$ & $(1.336)$ \\
Share turnover & $-9.895^{* * *}$ & $-7.216^{* *}$ & -0.008 & $-9.638^{* * *}$ & $-9.116^{* * *}$ & $-9.961^{* * *}$ \\
& $(-3.112)$ & $(-2.240)$ & & $(-2.974)$ & $(-2.835)$ & $(-3.125)$ \\
Stock return volatility & $9.063^{* *}$ & $11.887^{* * *}$ & 0.030 & $8.804^{* *}$ & $9.292^{* *}$ & $9.580^{* *}$ \\
& $(2.119)$ & $(2.840)$ & & $(2.103)$ & $(2.191)$ & $(2.251)$ \\
Z-score & $0.065^{* *}$ & $0.058^{* *}$ & 0.007 & $0.069^{* *}$ & $0.066^{* *}$ & $0.063^{* *}$ \\
& $(2.213)$ & $(2.108)$ & & $(2.425)$ & $(2.300)$ & $(2.152)$ \\
Year fixed effects & Yes & Yes & & Yes & Yes & Yes \\
Log pseudolikelihood & $-3363^{* * *}$ & $-3314^{* * *}$ & & $-3358^{* * *}$ & $-3359^{* * *}$ & $-3360^{* * *}$ \\
Observations & 11,942 & 11,942 & & 11,942 & 11,942 & 11,942 \\
Pseudo R-squared & 0.3296 & 0.3394 & & 0.3306 & 0.3304 & 0.3302 \\
\hline
\end{tabular}




\section{Table 8}

\section{The Multinomial Logit Regression with Payout Ratio}

This table reports the multinomial logit regression results of firms' choice among private equity, SEO, bank loan and public bond using firms issuing SEO as base outcome. Robust t-statistics clustered at the firm level are shown in parentheses. $* * *, * *$ and $*$ denote a significant level of 1 percent, 5 percent, and 10 percent, respectively.

(1)

(2)

\begin{tabular}{|c|c|c|c|c|c|c|}
\hline \multirow[b]{2}{*}{ VARIABLES } & & \\
\hline & $\begin{array}{l}\text { Private } \\
\text { equity }\end{array}$ & Loan & Bond & $\begin{array}{c}\text { Private } \\
\text { equity }\end{array}$ & Loan & Bond \\
\hline \multirow[t]{2}{*}{ Analyst coverage } & $0.046^{* *}$ & $-0.014^{*}$ & 0.012 & $0.048 * *$ & $-0.016^{* *}$ & 0.010 \\
\hline & $(2.313)$ & $(-1.933)$ & $(1.446)$ & $(2.392)$ & $(-2.235)$ & $(1.143)$ \\
\hline \multirow[t]{2}{*}{ Payout ratio decile } & & & & 0.030 & $0.111 * * *$ & $0.112 * * *$ \\
\hline & & & & $(1.081)$ & $(8.382)$ & $(5.748)$ \\
\hline \multirow[t]{2}{*}{ Firm size } & $-0.536^{* * *}$ & $0.267 * * *$ & $0.689 * * *$ & $-0.552 * * *$ & $0.231 * * *$ & $0.652 * * *$ \\
\hline & $(-6.165)$ & $(7.033)$ & (11.677) & $(-6.322)$ & $(6.085)$ & $(11.026)$ \\
\hline \multirow[t]{2}{*}{$\log ($ Age $)$} & $0.262 * * *$ & $0.307 * * *$ & $0.301 * * *$ & $0.241 * * *$ & $0.245^{* * *}$ & $0.240 * * *$ \\
\hline & $(3.372)$ & $(7.604)$ & $(4.493)$ & $(3.060)$ & $(5.974)$ & $(3.534)$ \\
\hline \multicolumn{7}{|l|}{ Leverage deviation } \\
\hline \multirow[t]{2}{*}{ (actual-target) } & $-1.022 *$ & -0.425 & 0.423 & -0.930 & -0.253 & 0.600 \\
\hline & $(-1.670)$ & $(-1.371)$ & $(0.871)$ & $(-1.530)$ & $(-0.817)$ & $(1.236)$ \\
\hline \multirow[t]{2}{*}{ Three-year mean ROA } & $-1.079 * * *$ & $2.342 * * *$ & $1.604 *$ & $-1.105 * * *$ & $2.061 * * *$ & 1.327 \\
\hline & $(-2.686)$ & $(6.363)$ & $(1.843)$ & $(-2.725)$ & $(5.764)$ & $(1.546)$ \\
\hline \multirow[t]{2}{*}{ One-year stock return } & $-0.355 * * *$ & $-0.799 * * *$ & $-0.707 * * *$ & $-0.347 * * *$ & $-0.761 * * *$ & $-0.666 * * *$ \\
\hline & $(-3.138)$ & $(-11.266)$ & $(-6.006)$ & $(-3.068)$ & $(-10.761)$ & $(-5.668)$ \\
\hline \multirow[t]{2}{*}{ Market-to-book ratio } & $-0.103 * *$ & $-0.077 * * *$ & 0.056 & $-0.105 * * *$ & $-0.084 * * *$ & 0.048 \\
\hline & $(-2.530)$ & $(-3.026)$ & $(0.934)$ & $(-2.580)$ & $(-3.286)$ & $(0.810)$ \\
\hline \multirow[t]{2}{*}{ Dummy for $M / B>1$} & -0.230 & $-0.515 * * *$ & -0.203 & -0.210 & $-0.507 * * *$ & -0.192 \\
\hline & $(-0.895)$ & $(-3.710)$ & $(-1.044)$ & $(-0.821)$ & $(-3.621)$ & $(-0.990)$ \\
\hline \multirow[t]{2}{*}{ Dilution dummy } & -0.300 & $0.458 * * *$ & $0.620 * * *$ & -0.310 & $0.392 * * *$ & $0.556^{* * *}$ \\
\hline & $(-1.387)$ & $(5.155)$ & $(5.163)$ & $(-1.436)$ & $(4.364)$ & $(4.620)$ \\
\hline \multirow[t]{2}{*}{ Tangible assets } & 0.507 & $-0.715 * * *$ & -0.134 & 0.488 & $-0.739 * * *$ & -0.159 \\
\hline & $(1.312)$ & $(-3.612)$ & $(-0.452)$ & $(1.263)$ & $(-3.735)$ & $(-0.534)$ \\
\hline \multirow[t]{2}{*}{ S\&P rating dummy } & 0.256 & 0.042 & $1.698 * * *$ & 0.251 & 0.035 & $1.691 * * *$ \\
\hline & $(0.943)$ & $(0.371)$ & $(9.792)$ & $(0.930)$ & $(0.307)$ & $(9.759)$ \\
\hline \multirow[t]{2}{*}{ Asset growth rate } & 0.124 & -0.079 & $0.196^{* *}$ & 0.137 & -0.061 & $0.214^{* *}$ \\
\hline & $(1.459)$ & $(-1.149)$ & $(2.047)$ & $(1.581)$ & $(-0.885)$ & $(2.253)$ \\
\hline \multirow[t]{2}{*}{$\mathrm{R} \& \mathrm{D}$ ratio } & $-1.230 * *$ & $-4.769 * * *$ & $-3.530 * *$ & $-1.195 * *$ & $-4.668 * * *$ & $-3.422 * *$ \\
\hline & $(-2.168)$ & $(-8.591)$ & $(-2.302)$ & $(-2.095)$ & $(-8.562)$ & $(-2.258)$ \\
\hline \multirow[t]{2}{*}{ R\&D dummy } & -0.039 & 0.105 & 0.131 & -0.014 & 0.120 & 0.147 \\
\hline & $(-0.207)$ & $(1.130)$ & $(0.927)$ & $(-0.077)$ & $(1.274)$ & $(1.032)$ \\
\hline \multirow[t]{2}{*}{ Share turnover } & $-9.897 *$ & $-10.537 * * *$ & $-32.888 * * *$ & $-8.922 *$ & $-8.097 * * *$ & $-30.357 * * *$ \\
\hline & $(-1.894)$ & $(-3.792)$ & $(-5.957)$ & $(-1.690)$ & $(-2.910)$ & $(-5.506)$ \\
\hline \multirow[t]{2}{*}{ Stock return volatility } & $19.519 * * *$ & $12.758 * * *$ & -0.408 & $21.129 * * *$ & $16.058^{* * *}$ & 3.324 \\
\hline & $(2.989)$ & (3.196) & $(-0.059)$ & $(3.186)$ & $(3.941)$ & $(0.477)$ \\
\hline
\end{tabular}




\begin{tabular}{lcccccc} 
Z-score & $-0.096^{* * *}$ & 0.010 & -0.062 & $-0.098^{* * *}$ & 0.000 & -0.072 \\
& $(-3.141)$ & $(0.345)$ & $(-1.095)$ & $(-3.184)$ & $(0.009)$ & $(-1.285)$ \\
Constant & -0.034 & 0.648 & $-5.656^{* * *}$ & -0.123 & 0.489 & $-5.837 * * *$ \\
& $(-0.041)$ & $(1.532)$ & $(-8.615)$ & $(-0.147)$ & $(1.155)$ & $(-8.931)$ \\
Year fixed effects & Yes & Yes & Yes & Yes & Yes & Yes \\
Log likelihood & & $-6696^{* * *}$ & & & $-6647 * * *$ & \\
Observations & & 11,942 & & & 11,940 & \\
Pseudo R-squared & & 0.3153 & & & 0.3199 & \\
\hline
\end{tabular}




\section{Table 9}

The Multinomial Logit Regression with the Other Three Criteria

This table reports the multinomial logit regression results of firms' choice among private equity, SEO, bank loan and public bond using firms issuing SEO as base outcome. Robust t-statistics clustered at the firm level are shown in parentheses. ***, ** and * denote a significant level of 1 percent, 5 percent, and 10 percent, respectively.

(1)

\begin{tabular}{lccc}
\cline { 2 - 4 } VARIABLES & $\begin{array}{c}\text { Private } \\
\text { equity }\end{array}$ & Loan & Bond \\
\hline Analyst coverage & $0.049^{* *}$ & $-0.013^{*}$ & 0.012 \\
& $(2.444)$ & $(-1.878)$ & $(1.406)$ \\
The KZ index decile & 0.033 & $0.071^{* * *}$ & 0.003 \\
& $(1.218)$ & $(3.870)$ & $(0.116)$
\end{tabular}

The WW index decile

The SA index decile

Firm size
Log(Age)
Leverage deviation

(actual-target)

Three-year mean ROA

One-year stock return
(2)

\begin{tabular}{ccc}
$\begin{array}{c}\text { Private } \\
\text { equity }\end{array}$ & Loan & Bond \\
\hline $0.051^{* *}$ & $-0.013^{*}$ & $0.014^{*}$ \\
$(2.561)$ & $(-1.789)$ & $(1.677)$ \\
& & \\
& & \\
0.005 & $-0.082 * *$ & $-0.239 * * *$ \\
$(0.121)$ & $(-2.449)$ & $(-4.459)$
\end{tabular}

$(0.121) \quad(-2.449) \quad(-4.459)$

$\begin{array}{cccccc}-0.556^{* * *} & 0.249 * * * & 0.690^{* * *} & -0.516^{* * *} & 0.168^{* * *} & 0.466 * * * \\ (-6.361) & (6.540) & (11.633) & (-5.109) & (2.970) & (5.819) \\ 0.273^{* * *} & 0.302 * * * & 0.279 * * * & 0.260^{* * *} & 0.290^{* * *} & 0.267 * * * \\ (3.469) & (7.463) & (4.117) & (3.256) & (7.134) & (3.928) \\ & & & & & \\ -1.274 * * & -0.981 * * * & 0.336 & -1.011^{*} & -0.390 & 0.559 \\ (-2.082) & (-2.921) & (0.637) & (-1.651) & (-1.246) & (1.138) \\ -1.118^{* * *} & 2.381^{* * *} & 1.453^{*} & -1.153^{* * *} & 2.404^{* * *} & 2.021 * * \\ (-2.751) & (6.475) & (1.678) & (-2.660) & (6.497) & (2.525) \\ -0.355^{* * *} & -0.806^{* * *} & -0.688^{* * *} & -0.388^{* * *} & -0.800^{* * *} & -0.685^{* * *}\end{array}$

\begin{tabular}{ccc}
\hline $\begin{array}{c}\text { Private } \\
\text { equity }\end{array}$ & Loan & Bond \\
\hline $0.035^{*}$ & $-0.014^{*}$ & $0.017^{* *}$ \\
$(1.787)$ & $(-1.932)$ & $(1.971)$ \\
& & \\
& & \\
& & \\
& & \\
$0.397 * * *$ & 0.035 & $-0.519^{* * *}$ \\
$(4.706)$ & $(0.782)$ & $(-6.234)$ \\
-0.051 & $0.298^{* * *}$ & $0.550^{* * *}$ \\
$(-0.363)$ & $(4.775)$ & $(6.964)$ \\
$0.734 * * *$ & $0.341 * * *$ & $-0.461 * * *$ \\
$(5.734)$ & $(5.006)$ & $(-3.462)$ \\
& & \\
$-1.014 *$ & -0.410 & 0.381 \\
$(-1.664)$ & $(-1.318)$ & $(0.775)$ \\
$-1.432^{* * *}$ & $2.314^{* * *}$ & 1.429 \\
$(-3.487)$ & $(6.270)$ & $(1.520)$ \\
$-0.372 * * *$ & $-0.802^{* * *}$ & $-0.693 * * *$
\end{tabular}

(3) 


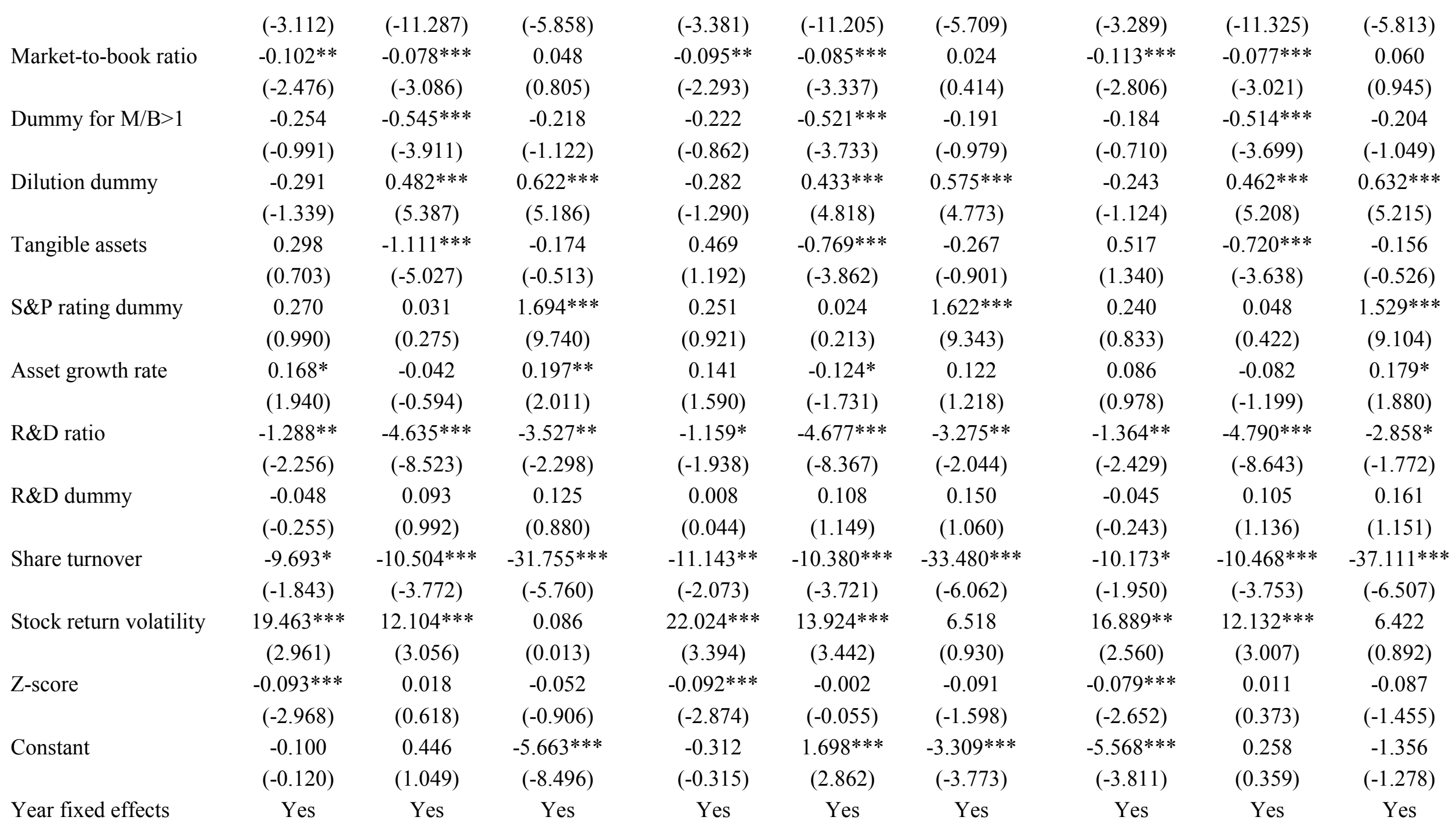


Log likelihood

$-6666^{* * *}$

$-6623 * * *$

$-6646^{* * *}$

Observations

11,923

11,879

11,942

Pseudo R-squared 
Figure 1 (a) Unconstrained firms

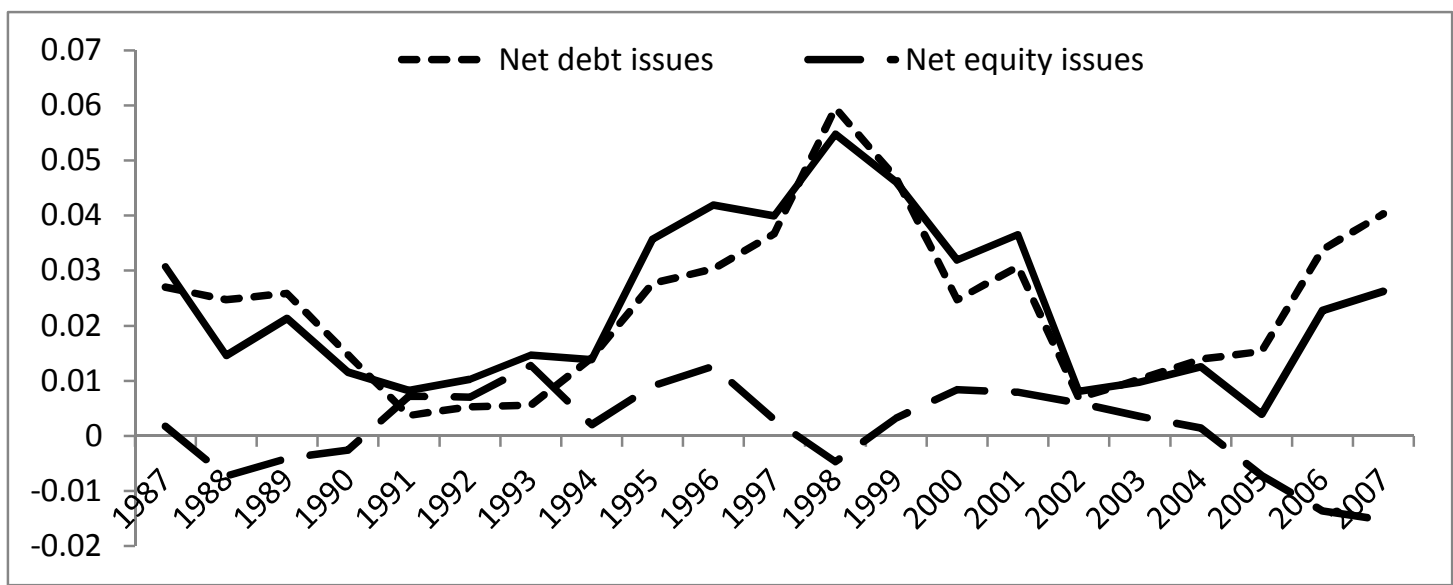

Figure 1 (b) Intermediate firms

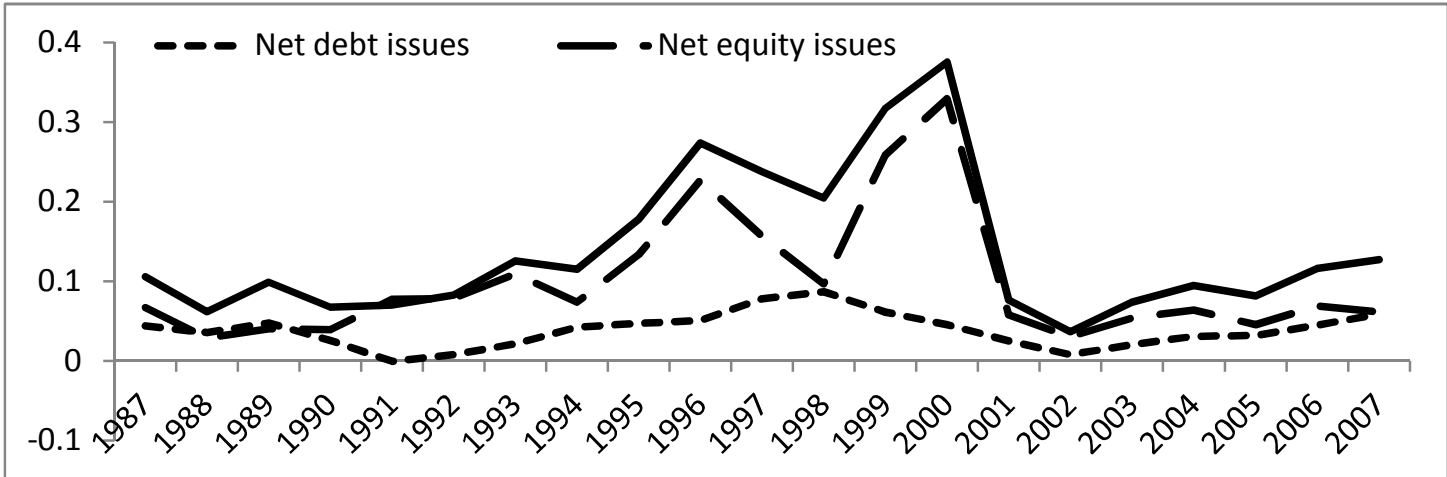

Figure 1 (c) Constrained firms

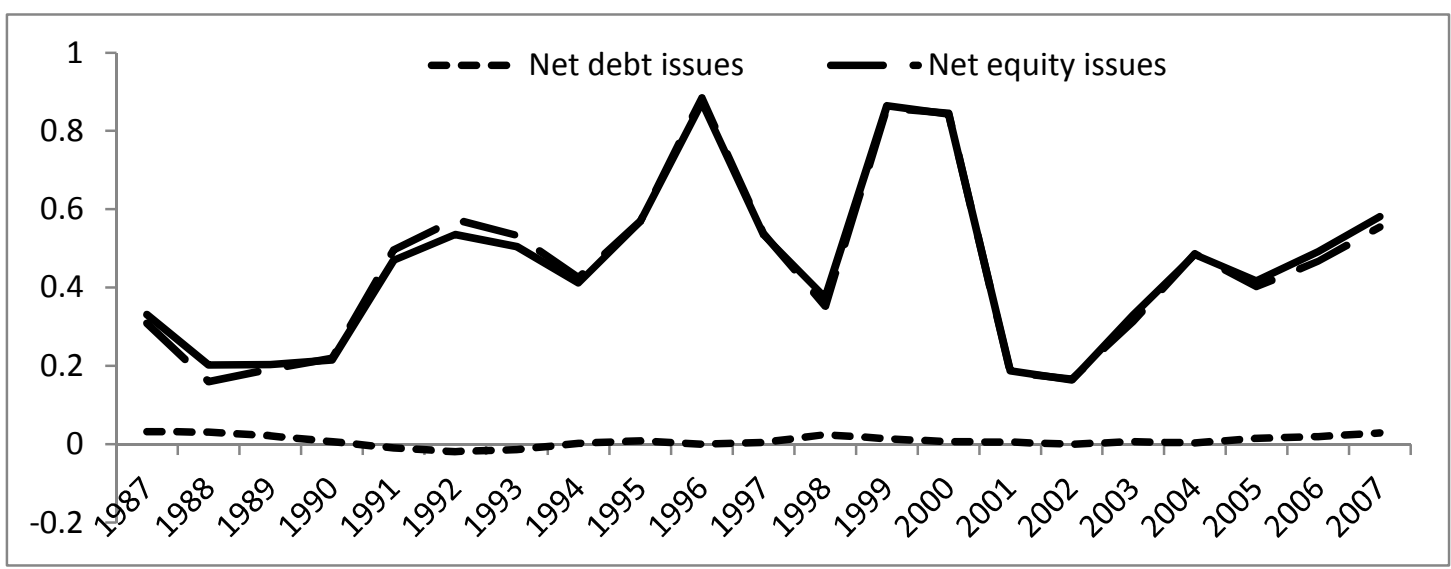

Figure 1 Financing deficit, net debt issues and net equity issues. Figure 1 graphs the relationship among financing deficit, net debt issues and net equity issues for the unconstrained, intermediate and constrained firms, respectively. We classify the firms into deciles based on the SA index in each year, and define firms in the top (bottom) three deciles as financially constrained (unconstrained) firms, while firms in-between as the intermediate firms. Here the SA index is calculated as $-0.737 \times$ Size $+0.043 \times$ Size $^{2}-0.040 \times$ Age as in Hadlock and Pierce (2010), where Size and Age have a upper bond of $\log (\$ 4.5$ billion $)$ and 37 years, respectively. The higher the SA index is, the more financial constraints a firm faces. 